\title{
Ultra-durable Ni-Ir/MgAl204 catalysts for dry reforming of methane enabled by dynamic balance between carbon deposition and elimination
}

Haocheng Li

East China Normal University

Cong Hao

Xiamen University

Jingqing Tian

East China Normal University

Shuai Wang

Xiamen University https://orcid.org/0000-0002-4618-4162

Chen Zhao ( $\nabla$ czhao@chem.ecnu.edu.cn )

East China Normal University

Article

Keywords:

Posted Date: February 11th, 2022

DOI: https://doi.org/10.21203/rs.3.rs-1335282/v1

License: (c) (i) This work is licensed under a Creative Commons Attribution 4.0 International License.

Read Full License 
Ultra-durable $\mathrm{Ni}-\mathrm{Ir} / \mathrm{MgAl}_{2} \mathrm{O}_{4}$ catalysts for dry

6 reforming of methane enabled by dynamic balance 


\section{Abstract}

Carbon deposition is the main cause for the catalyst deactivation of methane dry reforming, and researchers are committed to exploring effective catalyst systems with zero carbon deposition in order to achieve a practically long life-time. In this work, we propose an equilibrium theory with matched rates of $\mathrm{CH}_{4}$ dissociation and $\mathrm{CO}_{2}$ activation to establish a balance between carbon deposition and carbon elimination, and construct highly dispersed $\mathrm{Ni}-\mathrm{Ir} / \mathrm{MgAl}_{2} \mathrm{O}_{4}$ alloy catalysts accordingly, where $\mathrm{Ni}$ activated $\mathrm{CH}_{4}, \mathrm{MgAl}_{2} \mathrm{O}_{4}$ adsorbed $\mathrm{CO}_{2}$ to form surface carbonates, and Ir effectively utilized the carbonates to eliminate carbon species generated by $\mathrm{CH}_{4}$ dissociation. Theoretical assessment further unveiled that the preferred $\mathrm{CO}_{2}$ activation on Ir over $\mathrm{Ni}$ is derived from its stronger oxophilicity. With an optimal $\mathrm{Ni} / \mathrm{Ir}$ atomic ratio of $1 / 2$, high activity and long-period stability $(600 \mathrm{~h})$ with zero carbon deposition were obtained concurrently for dry reforming of methane at industrially-relevant temperature $\left(650^{\circ} \mathrm{C}\right)$. 


\section{Introduction}

Dry reforming of methane (DRM) is a primary method for producing syngas (a mixture of $\mathrm{CO}$ and $\mathrm{H}_{2}$ ) that acts as a key platform for the industrial production of fuels and chemicals ${ }^{[1-5]}$. Among group VIII metals ${ }^{[6-10]}$, low-cost Ni has drawn the most attention for DRM because of its strong $\mathrm{CH}_{4}$ dissociation ability, which endows $\mathrm{Ni}$ with an excellent catalytic performance of DRM ${ }^{[11-15]}$. However, Ni-based catalysts suffer from serious carbon deposition and metal sintering issues under the high-temperature condition of DRM $\left(700-1000{ }^{\circ} \mathrm{C}\right)$, which limits their large-scale application ${ }^{[16-20]}$. The main causes of carbon deposition include the disproportionation of carbon monoxide $\left(2 \mathrm{CO}(\mathrm{g}) \rightleftharpoons \mathrm{C}(\mathrm{s})+\mathrm{CO}_{2}(\mathrm{~g}) ; \Delta H=-171 \mathrm{~kJ} / \mathrm{mol}\right)$ and the deep dissociation of methane $\left(\mathrm{CH}_{4}(\mathrm{~g}) \rightleftharpoons \mathrm{C}(\mathrm{s})+2 \mathrm{H}_{2}(\mathrm{~g}) ; \Delta H=75 \mathrm{~kJ} / \mathrm{mol}\right)$, while the latter prevails at temperatures above $600{ }^{\circ} \mathrm{C}{ }^{[21]}$.

Various methods have been attempted to suppress the carbon deposits in DRM. By using supports rich in oxygen vacancies such as $\mathrm{CeO}_{2}{ }^{[22-24]}$ or alkaline oxide supports like $\mathrm{MgO}{ }^{[25-26]}, \mathrm{CO}_{2}$ activation can be strengthened to accelerate the elimination of carbon deposits. This enhances the redox property of the catalyst and inhibits the development of carbon deposition ${ }^{[27,28]}$. The accumulation and sintering of metallic $\mathrm{Ni}$ at high temperatures $\left(700-1000{ }^{\circ} \mathrm{C}\right)$ can result in the formation of larger Ni particles, which promotes the carbon deposition ${ }^{[29]}$. The strong metal-support interaction (SMSI) between metallic $\mathrm{Ni}$ and the hydroxyapatite $\left[\mathrm{Ca}_{10}\left(\mathrm{PO}_{4}\right)_{6}(\mathrm{OH})_{2}\right](\mathrm{HAP})$ support ${ }^{[30]}$ was found to enhance the dispersion of $\mathrm{Ni}$ particles and alleviate sintering and carbon deposits concurrently. In addition, it was reported that decorating the Ni surface with Co prevented the continuous formation of carbon nanotubes on the Ni surface ${ }^{[31]}$. The redox recycling on $\mathrm{Ni}-\mathrm{Fe} / \mathrm{Mg}_{\mathrm{x}} \mathrm{Al}_{\mathrm{y}} \mathrm{O}_{z}$ catalysts, where metallic $\mathrm{Fe}$ was oxidized by $\mathrm{CO}_{2}$ to form $\mathrm{FeO}_{\mathrm{x}}$ and the adsorbed $\mathrm{C}$ atom obtained from the dissociation of $\mathrm{CH}_{4}$ reduced $\mathrm{FeO}_{\mathrm{x}}$ back to $\mathrm{Fe}$, can effectively eliminate carbon deposits ${ }^{[32]}$. Ni-Mo nanoparticles were stabilized on the edge of a single $\mathrm{MgO}$ crystal to inhibit the particle sintering at high temperatures and effectively prevent the generation of carbon deposits over a long reaction period $(850 \mathrm{~h})^{[33]}$. 
The core issue for achieving practically-durable DRM catalysts with minimal carbon deposition is to establish an efficient equilibrium between $\mathrm{CH}_{4}$ dissociation and $\mathrm{CO}_{2}$ activation on the catalyst surface. In this work, we show that a highly efficient and stable DRM system can be built on bimetallic $\mathrm{Ni}-\mathrm{Ir} / \mathrm{MgAl}_{2} \mathrm{O}_{4}$ catalysts, brought forth by a synergy between the $\mathrm{CH}_{4}$ dissociation on $\mathrm{Ni}$ sites and $\mathrm{MgAl}_{2} \mathrm{O}_{4}$-enhanced $\mathrm{CO}_{2}$ adsorption and activation on Ir sites that can scavenge surface carbon species generated from the $\mathrm{CH}_{4}$ dissociation step. Through in-situ spectroscopic characterization of the generation and elimination of carbon species and theoretical calculations on the $\mathrm{CO}_{2}$ activation, we propose an equilibrium mechanism of carbon generation and elimination for designing the effective and durable catalysts for the DRM process.

\section{Results and discussion}

\section{Structural characterization of supported Ni-Ir catalysts}

$\mathrm{MgAl}_{2} \mathrm{O}_{4}$-supported $\mathrm{Ni}, \mathrm{Ni}_{3} \mathrm{Ir}_{1}$, and $\mathrm{Ir}$ catalysts were synthesized using a conventional co-impregnation method, and the surface areas of these catalysts were 126.0, 133.9, and $136.1 \mathrm{~m}^{2} / \mathrm{g}$, respectively, as determined by nitrogen physical adsorption (Fig. S1). X-ray diffraction (XRD) results (Fig. 1a) showed that the diffraction peaks of metallic $\mathrm{Ni}$ for $\mathrm{Ni}_{3} \mathrm{Ir}_{1} / \mathrm{MgAl}_{2} \mathrm{O}_{4}$ had a much lower intensity compared to the pure Ni catalyst. Similarly, compared with the pure Ir catalyst, the diffraction peaks of Ir had a lower intensity for $\mathrm{Ni}_{3} \mathrm{Ir}_{1} / \mathrm{MgAl}_{2} \mathrm{O}_{4}$. Such weakened diffraction peaks for the Ni-Ir catalyst implies that the interaction of $\mathrm{Ni}$ and Ir increased metal dispersion compared to the single-metal catalyst system. The Ni-Ir interaction is further evidenced by a shift of the signal peaks of metallic Ir in the presence of $\mathrm{Ni}$ (e.g., from $40.46^{\circ}$ to $40.92^{\circ}$ for the $\operatorname{Ir}(111)$ plane and from $47.12^{\circ}$ to $47.66^{\circ}$ for the $\operatorname{Ir}(200)$ plane, Fig. S2), consistent with the smaller atomic radius of Ni than Ir.

As shown in XPS profiles of Fig. $1 \mathrm{~b}$, the $\mathrm{Ni}^{0} 2 \mathrm{p}_{3 / 2}(855.2 \mathrm{eV})$ and $\mathrm{Ni}^{2+} 2 \mathrm{p}_{3 / 2}(858.2$ eV) signals were observed for the $\mathrm{Ni} / \mathrm{MgAl}_{2} \mathrm{O}_{4}$ catalyst. The presence of $\mathrm{Ni}^{2+}$ cations indicates the formation of $\mathrm{NiAl}_{2} \mathrm{O}_{4}$ species on the support surface during the synthesis process. Compared with $\mathrm{Ni} / \mathrm{MgAl}_{2} \mathrm{O}_{4}$, the $\mathrm{Ni}^{2+}$ content and binding energy position in 
the $\mathrm{Ni}_{3} \mathrm{Ir}_{1} / \mathrm{MgAl}_{2} \mathrm{O}_{4}$ catalyst changed minimally, while the $\mathrm{Ni}^{0} 2 \mathrm{p}_{3 / 2}$ signal increased to $858.6 \mathrm{eV}$ (by $0.4 \mathrm{eV}$ ). In contrast, the binding energy of $\operatorname{Ir}^{0} 4 \mathrm{f}_{2 / 7}$ was $62.2 \mathrm{eV}$ for the pure Ir catalyst (Fig. 1c), $0.4 \mathrm{eV}$ higher than that in the $\mathrm{Ni}_{3} \mathrm{Ir}_{1}$ catalyst $(61.8 \mathrm{eV})$. With respect to the monometallic $\mathrm{Ni}$ and Ir catalysts, these binding energy changes indicate the electrons were transferred from $\mathrm{Ni}$ to $\mathrm{Ir}$, suggesting the formation of $\mathrm{Ni}$-Ir alloy in the $\mathrm{Ni}-\mathrm{Ir} / \mathrm{MgAl}_{2} \mathrm{O}_{4}$ system. Ni and Ir K-edge X-ray adsorption fine structure (XAFS) spectroscopy was also used to identify the localized structure of the Ni-Ir alloy (Fig. S3, Table S1), which shows the existence of Ni-Ir coordination bonds $(2.63-2.65 \AA)$ in the $\mathrm{Ni}_{3} \mathrm{Ir}_{1} / \mathrm{MgAl}_{2} \mathrm{O}_{4}$ catalyst.

The structural information for the $\mathrm{Ni}_{3} \mathrm{Ir}_{1} / \mathrm{MgAl}_{2} \mathrm{O}_{4}$ catalyst was further confirmed by transmission electron microscopy (TEM) and energy dispersive spectroscopy (EDS) elemental mapping (Figs. 1d-g). The metal nanoparticles were uniformly dispersed on the $\mathrm{MgAl}_{2} \mathrm{O}_{4}$ spinel support surface with a typical bimodal particle size distribution, for which the corresponding average particle diameters were 1.2 and $4.3 \mathrm{~nm}$ and the smaller particles were predominant. In contrast, the average diameters of metal particles for $\mathrm{Ir} / \mathrm{MgAl}_{2} \mathrm{O}_{4}$ and $\mathrm{Ni} / \mathrm{MgAl}_{2} \mathrm{O}_{4}$ were 1.1 and $5.7 \mathrm{~nm}$, respectively (Fig. S4). It is clearly indicated that the formation of the $\mathrm{Ni}-\mathrm{Ir}$ alloy improved the dispersion of $\mathrm{Ni}$, consistent with the XRD results shown above (Fig. 1a). In addition, the EDS analysis (Fig. 1e) showed that the small particles in the $\mathrm{Ni}_{3} \operatorname{Ir}_{1} / \mathrm{MgAl}_{2} \mathrm{O}_{4}$ catalyst possessed a higher content of $\operatorname{Ir}(\mathrm{Ni} / \mathrm{Ir} \approx 2 / 3)$, while $\mathrm{Ni}$ dominated in the large particles $(\mathrm{Ni} / \mathrm{Ir} \approx 4 / 1)$. The uniform distributions of the $\mathrm{Ni}$ and Ir elements within each kind of the Ni-Ir particles (Figs. 1f-g, S5) agree well with the formation of alloys in the $\mathrm{Ni}-\mathrm{Ir} / \mathrm{MgAl}_{2} \mathrm{O}_{4}$ catalyst. Taken together, XRD, XPS, XAFS, TEM, and EDS were combined to verify that Ni-Ir alloys were formed in the bimetallic $\mathrm{Ni}-\mathrm{Ir} / \mathrm{MgAl}_{2} \mathrm{O}_{4}$ system, which significantly improved the dispersion of the Ni nanoparticles on the $\mathrm{MgAl}_{2} \mathrm{O}_{4}$ support and provided a basis for the efficient coupling between $\mathrm{CH}_{4}$ dissociation and $\mathrm{CO}_{2}$ activation on the $\mathrm{Ni}$ and Ir active sites, respectively, as demonstrated next for DRM. 

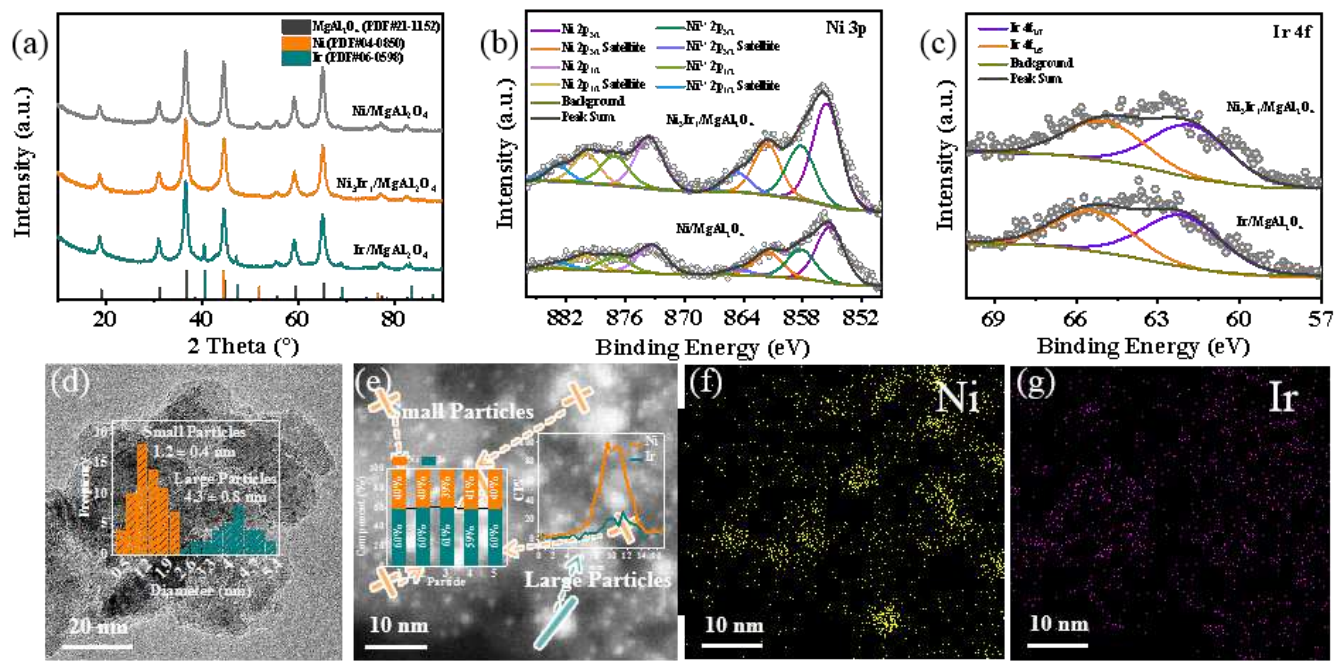

Fig. 1 (a) XRD patterns of $\mathrm{Ni} / \mathrm{MgAl}_{2} \mathrm{O}_{4}, \mathrm{Ni}-\mathrm{Ir} / \mathrm{MgAl}_{2} \mathrm{O}_{4}$, and $\mathrm{Ir} / \mathrm{MgAl}_{2} \mathrm{O}_{4}$, (b) Ni $3 p$ XPS patterns of $\mathrm{Ni} / \mathrm{MgAl}_{2} \mathrm{O}_{4}$ and $\mathrm{Ni}_{3} \operatorname{Ir}_{1} / \mathrm{MgAl}_{2} \mathrm{O}_{4}$, (c) Ir $4 \mathrm{f}$ XPS patterns of

$\mathrm{Ni}_{3} \mathrm{Ir}_{1} / \mathrm{MgAl}_{2} \mathrm{O}_{4}$ and $\mathrm{Ir} / \mathrm{MgAl}_{2} \mathrm{O}_{4}$, (d) HRTEM and particle size distribution of the metal nanoparticles, (e) EDS, and (f-g) EDS-mapping of $\mathrm{Ni}_{3} \mathrm{Ir}_{1} / \mathrm{MgAl}_{2} \mathrm{O}_{4}$.

\section{Catalytic performances of Ni-Ir catalysts in DRM}

From the view of thermodynamics, the DRM process is favorable at high temperatures due to its endothermic nature. At medium to low temperatures (below $700{ }^{\circ} \mathrm{C}$ ), the impact of carbon deposits will be significant. The results for the $\mathrm{Ni} / \mathrm{MgAl}_{2} \mathrm{O}_{4}, \mathrm{Ni}_{3} \mathrm{Ir}_{1} / \mathrm{MgAl}_{2} \mathrm{O}_{4}$, and $\mathrm{Ir} / \mathrm{MgAl}_{2} \mathrm{O}_{4}$ catalysts are shown in Figs. $2 \mathrm{a}$ and $\mathrm{S} 6$ $\left(650{ }^{\circ} \mathrm{C}\right.$, GHSV $\left.=40,000 \mathrm{~mL} \cdot \mathrm{g}^{-1} \cdot \mathrm{h}^{-1}, 1 \mathrm{bar}\right)$. For the pure Ni catalyst, the initial conversion of $\mathrm{CH}_{4}$ was $59.4 \%$ and decreased to $47.3 \%$ after 100 hours of testing, in which the corresponding conversion of $\mathrm{CO}_{2}$ decreased from $71.5 \%$ to $61.6 \%$. It is reflected that the Ni catalyst was not able to maintain a good stability during DRM, although its initial activity was high. For the Ir catalyst, the initial conversions of $\mathrm{CH}_{4}$ and $\mathrm{CO}_{2}$ were only $50.2 \%$ and $63.6 \%$, respectively, but the catalyst activity did not decrease significantly during the 100 -hour test. For the $\mathrm{Ni}_{3} \operatorname{Ir}_{1} / \mathrm{MgAl}_{2} \mathrm{O}_{4}$ catalysts, the conversions of $\mathrm{CH}_{4}$ and $\mathrm{CO}_{2}$ slightly decreased from $61.5 \%$ to $60.2 \%$ and $73.3 \%$ to $72.8 \%$ during the 100-hour test, respectively, indicating the Ni-Ir alloy catalyst possessed both of high activity and improved stability. As shown in Table S2, we summarize the typical catalyst systems for DRM, and the $\mathrm{Ni}-\mathrm{Ir} / \mathrm{MgAl}_{2} \mathrm{O}_{4}$ system 
developed in our study had superior conversion rates of $\mathrm{CH}_{4}$ and $\mathrm{CO}_{2}$ than the state-ofthe-art catalysts ${ }^{[9,34-41]}$.

For the DRM test with different temperatures $\left(600-800{ }^{\circ} \mathrm{C}\right.$, Fig. S7), the initial conversion of $\mathrm{CH}_{4}$ on the $\mathrm{Ni}, \mathrm{Ni}_{3} \mathrm{Ir}_{1}$ and $\mathrm{Ir}$ catalysts increased with increasing temperature from $42.1 \%, 46.8 \%$, and $20.9 \%$ at $600{ }^{\circ} \mathrm{C}$ to $89.8 \%, 90.4 \%$, and $90.2 \%$ at $800{ }^{\circ} \mathrm{C}$, respectively. Although the three catalysts showed significant differences in activity at the lower temperature, the gap decreased as the temperature increased until the activity was almost identical at $800{ }^{\circ} \mathrm{C}$. The ratio of $\mathrm{H}_{2} / \mathrm{CO}$ in the syngas showed a similar phenomenon, increasing from $0.67,0.80$, and 0.60 at $600^{\circ} \mathrm{C}$ to $0.96,0.97$, and 0.94 at $800{ }^{\circ} \mathrm{C}$. It is suggested that DRM is preferred over the reverse water-gas shift reaction (RWGS; $\mathrm{CO}_{2}+\mathrm{H}_{2} \rightarrow \mathrm{CO}+\mathrm{H}_{2} \mathrm{O}$ ) at temperatures above $600{ }^{\circ} \mathrm{C}$, which leads to an increase in the $\mathrm{H}_{2} / \mathrm{CO}$ ratio and gradually approaches unity as the temperature rises.

The different performances of the three catalysts in DRM may be directly related to their intrinsic abilities for the adsorption and activation of the $\mathrm{CH}_{4}$ and $\mathrm{CO}_{2}$ reactants. Kinetic studies (Figs. 2e-f) showed that the measured reaction order of $\mathrm{CO}_{2}$ for $\mathrm{Ni} / \mathrm{MgAl}_{2} \mathrm{O}_{4}$ was 0.12 , while for $\mathrm{Ni}_{3} \mathrm{Ir}_{1} / \mathrm{MgAl}_{2} \mathrm{O}_{4}$ and $\mathrm{Ir} / \mathrm{MgAl}_{2} \mathrm{O}_{4}$, the reaction order values were -0.13 and -0.57 , respectively. These data indicate the adsorption strength of $\mathrm{CO}_{2}$ on the three catalysts decreased with an order of $\mathrm{Ir} / \mathrm{MgAl}_{2} \mathrm{O}_{4}, \mathrm{Ni}_{3} \mathrm{Ir}_{1} / \mathrm{MgAl}_{2} \mathrm{O}_{4}$, and $\mathrm{Ni} / \mathrm{MgAl}_{2} \mathrm{O}_{4}$. As shown below, DFT calculations unveil that the higher oxophilicity of Ir than $\mathrm{Ni}$ accounts for the stronger $\mathrm{CO}_{2}$ adsorption on $\mathrm{Ir} / \mathrm{MgAl}_{2} \mathrm{O}_{4}$.

The measured reaction orders for $\mathrm{CH}_{4}$ over the $\mathrm{Ni}, \mathrm{Ni}_{3} \mathrm{Ir}_{1}$, and Ir catalysts were $-0.38,-0.50$, and -1.14 , respectively, indicating the dissociative adsorption of $\mathrm{CH}_{4}$ on $\mathrm{Ir} / \mathrm{MgAl}_{2} \mathrm{O}_{4}$ was also the strongest among the three catalysts. This outstanding adsorption ability of Ir made it difficult for the reactive species to desorb from the catalyst surface, which limited the catalytic activity at medium to low temperatures. As the temperature increased, the desorption of the reactive species became easier and the catalytic activity of $\mathrm{Ir} / \mathrm{MgAl}_{2} \mathrm{O}_{4}$ increased faster compared with the other two catalysts as evidenced by the changes of $\mathrm{CH}_{4}$ conversion with increasing temperature (Fig. S7). 


\section{Characterization of spent $\mathrm{Ni}-\mathrm{Ir}$ catalysts}

It is generally accepted that carbon deposition is one of the main causes of catalyst deactivation in DRM ${ }^{[16,18]}$. SEM images (Figs. 2b-d) of the spent catalysts clearly showed the appearance of carbon deposits after the DRM reaction, which were interlaced and attached to the catalyst surface, blocking contact between the active metal site and the reactants and thus inhibiting the catalytic activity. Specifically, $\mathrm{Ni} / \mathrm{MgAl}_{2} \mathrm{O}_{4}$ had more carbon deposits than $\mathrm{Ni}_{3} \mathrm{Ir}_{1} / \mathrm{MgAl}_{2} \mathrm{O}_{4}$, and the carbon chains on $\mathrm{Ni} / \mathrm{MgAl}_{2} \mathrm{O}_{4}$ were longer and thicker than the latter, with average diameters of about $27.9 \mathrm{~nm}$ versus $21.5 \mathrm{~nm}$. The carbon deposits also showed different morphologies for each catalyst, presumably due to the different amount of carbon species provided for the carbon chain growth for each catalyst. It is worth noting that the carbon deposition was nearly negligible on the Ir catalyst (Fig. 2d), consistent with the high stability of this catalyst for DRM.

XRD patterns of the spent $\mathrm{Ni} / \mathrm{MgAl}_{2} \mathrm{O}_{4}$ catalyst showed an obvious graphite- $2 \mathrm{H}$ signal $\left(2 \theta=25.9^{\circ}\right)$, which is typical of amorphous carbon species produced in DRM (Fig. 2g). The intensity of the graphite-2H signal for $\mathrm{Ni}_{3} \mathrm{Ir}_{1}$ was lower than that for $\mathrm{Ni}$, while this signal was not detectable on the Ir catalyst. Raman spectra of these spent catalysts (Fig. 2h) showed peaks at 1334 and $1598 \mathrm{~cm}^{-1}$ for both $\mathrm{Ni}$ and $\mathrm{Ni}_{3} \mathrm{Ir}_{1}$, which were assigned to the D-band and G-band signals of carbon species. Although the peak intensity of $\mathrm{Ni}$ was higher, the peak intensity ratios of the D-band and G-band signals were similar between the two catalysts, indicating no significant differences in the types of carbon deposits formed. For the spent Ir catalyst, no corresponding peaks were observed, consistent with the XRD characterization. To quantify the amount of carbon deposits formed on the spent catalysts, TGA analysis was conducted (Fig. 2i). No significant weight loss was observed for the Ir catalyst during the TGA process, while the $\mathrm{Ni}$ and $\mathrm{Ni}_{3} \mathrm{Ir}_{1}$ catalysts showed weight losses of $16.7 \%$ and $10.2 \%$, respectively. These data unambiguously reflect that the addition of Ir suppressed the formation of carbon deposits in DRM.

TEM characterization was further applied to analyze the structure and morphology of the spent catalysts after long-time reaction (Fig. S8). The average diameter of the Ni 
nanoparticles on $\mathrm{Ni} / \mathrm{MgAl}_{2} \mathrm{O}_{4}$ increased from 5.7 to $8.2 \mathrm{~nm}(5.7 \mathrm{~nm}$ for the fresh sample) after 100 hours of testing, indicative a severe sintering of the Ni particles at the condition of DRM. In contrast, the metal particle sizes of the spent $\mathrm{Ni}_{3} \mathrm{Ir}_{1}$ and $\mathrm{Ir}$ catalysts (1.2 and $4.1 \mathrm{~nm}$ for $\mathrm{Ni}_{3} \mathrm{Ir}_{1} / \mathrm{MgAl}_{2} \mathrm{O}_{4} ; 1.1 \mathrm{~nm}$ for $\mathrm{Ir} / \mathrm{MgAl}_{2} \mathrm{O}_{4}$ ) did not change significantly compared with the fresh ones. It is surmised that metallic Ir has a strong interaction with the $\mathrm{MgAl}_{2} \mathrm{O}_{4}$ support, which results in the smaller metal particles and stronger anti-sintering ability for the Ir-containing catalysts.
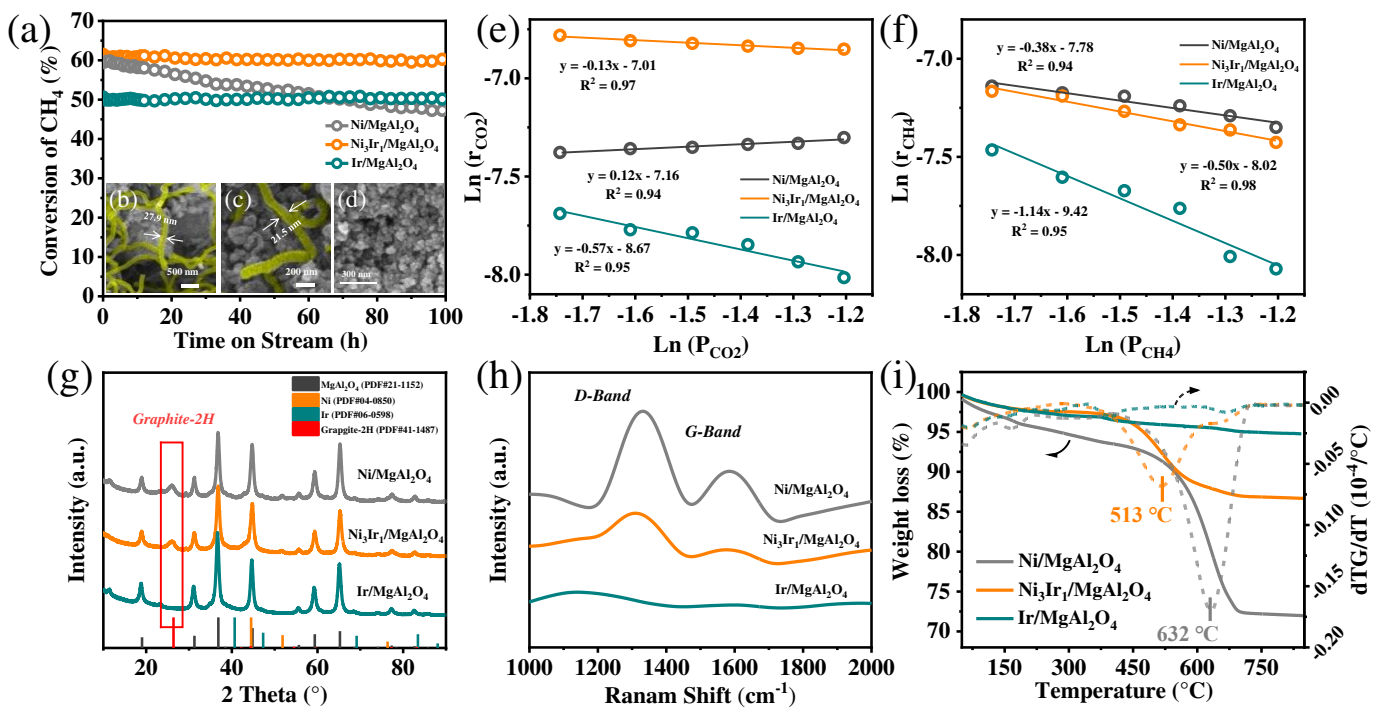

Fig. 2 (a) $\mathrm{CH}_{4}$ conversion on $\mathrm{Ni} / \mathrm{MgAl}_{2} \mathrm{O}_{4}, \mathrm{Ni}_{3} \mathrm{Ir}_{1} / \mathrm{MgAl}_{2} \mathrm{O}_{4}$, and $\mathrm{Ir} / \mathrm{MgAl}_{2} \mathrm{O}_{4}$ (reaction conditions for the catalytic test: $650{ }^{\circ} \mathrm{C}, \mathrm{CH}_{4} / \mathrm{CO}_{2}=1 / 1$, GHSV $=40,000 \mathrm{~mL} \cdot \mathrm{g}^{-1} \cdot \mathrm{h}^{-1}$, and 1 bar); (e-f) kinetic analysis; (b-d) SEM images, (g) XRD patterns, (h) Raman spectra, (i) TGA, and of the spent catalysts.

\section{In-situ DRIFTS study of DRM}

Adsorption of $\mathrm{CO}_{2}$ on the $\mathrm{MgAl}_{2} \mathrm{O}_{4}$ support can form carbonate species, which may promote the fixation and activation of $\mathrm{CO}_{2}$ during the DRM. In-situ diffuse reflectance infrared fourier transform spectroscopy (DRIFTS) analysis showed that $\mathrm{MgAl}_{2} \mathrm{O}_{4}$ adsorbed $\mathrm{CO}_{2}$ and converted it into carbonate species readily at $650{ }^{\circ} \mathrm{C}$ in a $\mathrm{CO}_{2}$ atmosphere (Fig. S9a). TGA was further performed to assess the $\mathrm{CO}_{2}$ adsorption capacity of $\mathrm{MgAl}_{2} \mathrm{O}_{4}$ (Fig. S9b), which was approximately $1.0 \mathrm{wt} \%$ at $650{ }^{\circ} \mathrm{C}$. As the temperature decreased, the adsorption capacity of $\mathrm{MgAl}_{2} \mathrm{O}_{4}$ continued to increase, and 
reached about $2.6 \mathrm{wt} \%$ at $50{ }^{\circ} \mathrm{C}$. Although the adsorption capacity was not significant at high temperatures, the adsorption and desorption of $\mathrm{CO}_{2}$ occurred simultaneously during the DRM process and could dynamically provide $\mathrm{CO}_{2}$ for the active metal sites, beneficial for the capture and utilization of gaseous $\mathrm{CO}_{2}$.

To further ascertain the specific impact of carbonates on $\mathrm{MgAl}_{2} \mathrm{O}_{4}$ for DRM, insitu DRIFTS was employed to analyze the activation process through the step-by-step introduction of $\mathrm{CO}_{2}-\mathrm{CH}_{4}-\mathrm{CO}_{2}$ atmosphere. Within the first minute of introducing $\mathrm{CO}_{2}$, all the three catalysts showed vibrational peaks at 1643 and $1542 \mathrm{~cm}^{-1}$ (attributed to monodentate carbonate species ${ }^{[42-43]}$ ), indicating all the catalysts can adsorb $\mathrm{CO}_{2}$ to form carbonate (Fig. S10). Subsequently, the IR reactor cell was purged with Ar, and $\mathrm{CH}_{4}$ was introduced in the second stage. The in-situ DRIFTS spectra for the three catalysts during the $\mathrm{CH}_{4}$ stage are shown in Figs. 3a-c; the carbonate signals slowly decreased over time and those for $\mathrm{Ni} / \mathrm{MgAl}_{2} \mathrm{O}_{4}$ decreased faster than the other two catalysts. It is worth noting that, at the beginning of the $\mathrm{CH}_{4}$ stage for $\mathrm{Ni} / \mathrm{MgAl}_{2} \mathrm{O}_{4}$, the gaseous $\mathrm{CO}_{2}$ signal initially increased and then slowly decreased; however, no gaseous $\mathrm{CO}_{2}$ was detectable on the other two catalysts. In addition, all the catalysts were observed generating $\mathrm{CO}$ (twin peak at $2150 \mathrm{~cm}^{-1}$ ), and the generation rate of $\mathrm{CO}$ was relatively slow on the $\mathrm{Ni} / \mathrm{MgAl}_{2} \mathrm{O}_{4}$ catalyst, with a noticeable $\mathrm{CO}$ signal observed only after 1 minute of introducing $\mathrm{CH}_{4}$, while the other catalysts showed obvious $\mathrm{CO}$ formation upon the initiation of the stage.

In the third stage, we again used Ar to purge the residual $\mathrm{CH}_{4}$ and then reintroduced $\mathrm{CO}_{2}$. The in-situ DRIFTS spectra of the catalysts during this stage again showed that carbonate species were formed on the catalysts (Figs. 3d-f). This occurred more slowly on the $\mathrm{Ni} / \mathrm{MgAl}_{2} \mathrm{O}_{4}$ catalyst, requiring 2.5 minutes to reach carbonate species saturation while on the other two catalysts, the saturation was reached after just 1 minute. Further, the signal peak for gaseous $\mathrm{CO}$ only appeared for the $\mathrm{Ni}_{3} \mathrm{Ir}_{1} / \mathrm{MgAl}_{2} \mathrm{O}_{4}$ catalyst.

Two distinct reaction pathways are proposed to explain the observed difference during the in-situ DRIFTS experiments described above. The $\mathrm{Ni} / \mathrm{MgAl}_{2} \mathrm{O}_{4}$ catalyst followed reaction path A (Fig. 3g). Namely, when $\mathrm{CO}_{2}$ was first introduced, the $\mathrm{MgAl}_{2} \mathrm{O}_{4}$ support adsorbed gaseous $\mathrm{CO}_{2}$ and formed monodentate carbonate species 
$241\left(\mathrm{CO}_{2}(\mathrm{~g}) \rightarrow \mathrm{CO}_{3}{ }^{2-}\right.$, ads $)$, thus allowing the carbonate species to reach saturation. When

$242 \mathrm{CH}_{4}$ was introduced in the second stage, it was dissociated on the active metal sites, 243 forming surface $\mathrm{CH}_{\mathrm{x}} *(\mathrm{x}=0-3)$ species $\left(\mathrm{CH}_{4}(\mathrm{~g}) \rightarrow \mathrm{H}^{*}+\mathrm{CH}_{\mathrm{x}}{ }^{*}\right)$, which continued to 244 accumulate and form carbon deposits. The carbonate species on $\mathrm{MgAl}_{2} \mathrm{O}_{4}$ cannot be 245 used by the active $\mathrm{Ni}$ sites directly, while it can decompose into gaseous $\mathrm{CO}_{2}\left(\mathrm{CO}_{3}{ }^{2-}\right.$ ads $\left.246 \rightarrow \mathrm{CO}_{2}(\mathrm{~g})\right)$ again, which then adsorbed on the active Ni sites and further reacted with $\mathrm{CH}_{\mathrm{x}} *$ to form $\mathrm{CO} *\left(\mathrm{CO}_{2} *+\mathrm{CH}_{\mathrm{x}} * \rightarrow 2 \mathrm{CO}(\mathrm{g})+\mathrm{x} / 2 \mathrm{H}_{2}\right)$. $\mathrm{CO} *$ was finally released from 248 the catalyst surface to form gaseous $\mathrm{CO}$. Therefore, when $\mathrm{CH}_{4}$ was introduced during 249 the second stage, $\mathrm{CO}$ was not produced until sufficient carbonate was consumed to 250 generate $\mathrm{CO}_{2}$. Only easily eliminated carbon species were activated and removed by 251 the reaction with $\mathrm{CO}_{2}$ released by the support in the second stage, leaving the catalyst 252 surface covered by the recalcitrant carbon chains produced by overgrowth. Since Ni 253 could not effectively activate and utilize $\mathrm{CO}_{2}$ to eliminate the carbon chains, when $\mathrm{CO}_{2}$ was reintroduced in the third stage, only the accumulation of carbonate species on the support occurred without the formation of CO.

In contrast to $\mathrm{Ni} / \mathrm{MgAl}_{2} \mathrm{O}_{4}$, the $\mathrm{Ir} / \mathrm{MgAl}_{2} \mathrm{O}_{4}$ catalyst followed reaction path $\mathrm{B}$ (Fig. 3h). The difference was that the Ir active sites could directly use and activate the carbonate species on the support, eliminating the $\mathrm{CH}_{\mathrm{x}}{ }^{*}$ and forming gaseous $\mathrm{CO}\left(\mathrm{CO}_{3}{ }^{2-}\right.$, ads $\left.+\mathrm{CH}_{\mathrm{x}}{ }^{*} \rightarrow \mathrm{CO}(\mathrm{g})\right)$. The carbonate species did not have to decompose into $\mathrm{CO}_{2}(\mathrm{~g})$ to be reused, therefore there was a large amount of $\mathrm{CO}$ formed without obvious $\mathrm{CO}_{2}$ formation. The direct utilization of carbonate on the Ir based catalysts increased the utilization rate of carbonate species, resulting in a slower rate of consumption compared to route $\mathrm{A}$. Compared with $\mathrm{Ni}$, Ir had an insufficient ability to activate $\mathrm{CH}_{4}$, therefore the carbonate species that adsorbed on the surface of $\mathrm{MgAl}_{2} \mathrm{O}_{4}$ in the first stage was sufficient to eliminate the $\mathrm{CH}_{\mathrm{x}}{ }^{*}$ generated during the second stage, which resulted in no $\mathrm{CO}$ formation in the third stage. We also increased the time for $\mathrm{CH}_{4}$ introduction in the second stage of the $\mathrm{Ir} / \mathrm{MgAl}_{2} \mathrm{O}_{4}$ catalyst to ensure that enough $\mathrm{CH}_{\mathrm{x}}{ }^{*}$ were generated. After $\mathrm{CO}_{2}$ was introduced again, gaseous $\mathrm{CO}$ signals appeared indicating that the $\mathrm{Ir} / \mathrm{MgAl}_{2} \mathrm{O}_{4}$ catalyst could reduce the carbon species and $\mathrm{CO}_{2}$ to $\mathrm{CO}$ (Fig. S11).

The $\mathrm{Ni}_{3} \mathrm{Ir}_{1} / \mathrm{MgAl}_{2} \mathrm{O}_{4}$ catalyst also followed reaction path $\mathrm{B}$. Due to the presence 
of $\mathrm{Ni}$, the dissociation ability of $\mathrm{CH}_{4}$ was better than the $\mathrm{Ir} / \mathrm{MgAl}_{2} \mathrm{O}_{4}$ catalyst, therefore $\mathrm{CH}_{\mathrm{x}}{ }^{*}$ species were not completely eliminated and grew into carbon chains in the second stage. In the third stage, gaseous $\mathrm{CO}$ formed in addition to the carbonate but was slower because the carbonate was not saturated during the initial stage of $\mathrm{CO}_{2}$ introduction. With saturation of the carbonate species, the formation rate of gaseous $\mathrm{CO}$ increased accordingly, which further confirmed that carbonate was used as a bridge to adsorb and convert $\mathrm{CO}_{2}$ rather than directly utilize gaseous $\mathrm{CO}_{2}$. Both the $\mathrm{Ni}_{3} \mathrm{Ir}_{1} / \mathrm{MgAl}_{2} \mathrm{O}_{4}$ and $\mathrm{Ni} / \mathrm{MgAl}_{2} \mathrm{O}_{4}$ catalysts generated carbon species, which grew into carbon chains in the second stage. However, in the third stage, only the $\mathrm{Ni}_{3} \mathrm{Ir}_{1} / \mathrm{MgAl}_{2} \mathrm{O}_{4}$ catalyst following path $\mathrm{B}$ eliminated the carbon species completely and formed gaseous $\mathrm{CO}$. This suggests that path $\mathrm{B}$ was more beneficial to the activation of $\mathrm{CO}_{2}$ and the elimination of carbon species.

To verify the unique roles of $\mathrm{MgAl}_{2} \mathrm{O}_{4}$ in the $\mathrm{DRM}$, an $\mathrm{Ir} / \mathrm{Al}_{2} \mathrm{O}_{3}$ catalyst was further characterized by the in-situ DRIFTS experiment (Fig. S12). When $\mathrm{CO}_{2}$ was introduced in the first stage, no carbonate species formed and only obvious gaseous $\mathrm{CO}_{2}$ signal peaks appeared. In the second stage, no gaseous $\mathrm{CO}$ signal peak appeared during the introduction of $\mathrm{CH}_{4}$, because the carbon species were eliminated in a $\mathrm{CH}_{4}$ atmosphere without carbonates formed on the support surface. The third stage was the same as the second stage, with no obvious gaseous CO signal peaks. Although carbon species were produced by the activation of $\mathrm{CH}_{4}$ (TPSR-MS, in-situ DRIFTS) in the second stage, Ir weakly utilized gaseous $\mathrm{CO}_{2}$ to eliminate carbon species, and only a small amount of carbon species which had not continued to grow was further activated, forming a small amount of CO. Therefore, only the Ir-CO signal $\left(2000 \mathrm{~cm}^{-1}\right)$ was observed on the Ir catalyst, and the amount of gaseous $\mathrm{CO}$ did not reach the detection limit. This proves that the carbonate formed on the $\mathrm{MgAl}_{2} \mathrm{O}_{4}$ support played a key role in the effective removal of carbon by Ir during the DRM.

In order to further explore the adsorption and activation ability of $\mathrm{CO}_{2}$ on different catalysts, the catalysts were characterized with temperature programmed desorption of $\mathrm{CO}_{2}\left(\mathrm{CO}_{2}\right.$-TPD) showed a signal peak appeared only at $614{ }^{\circ} \mathrm{C}$ on $\mathrm{MgAl}_{2} \mathrm{O}_{4}$, and the peak position of $\mathrm{Ni} / \mathrm{MgAl}_{2} \mathrm{O}_{4}$ was similar to that of $\mathrm{MgAl}_{2} \mathrm{O}_{4}$, but with a lower intensity 
301 (Fig. S13). For $\mathrm{Ni}_{3} \mathrm{Ir}_{1} / \mathrm{MgAl}_{2} \mathrm{O}_{4}$, in addition to a peak appeared at $621{ }^{\circ} \mathrm{C}$ (similar to the 302 support), there were peaks at 778 and $873{ }^{\circ} \mathrm{C}$, and the peaks at $621^{\circ} \mathrm{C}$ and $809^{\circ} \mathrm{C}$ were 303 present for $\operatorname{Ir} / \mathrm{MgAl}_{2} \mathrm{O}_{4}$. This was because Ir had better dispersion and $\mathrm{CO}_{2}$ could be 304 effectively adsorbed and utilized at the $\mathrm{Ir}-\mathrm{MgAl}_{2} \mathrm{O}_{4}$ interface, while the $\mathrm{Ni}-\mathrm{MgAl}_{2} \mathrm{O}_{4}$ 305 interface has no effect on $\mathrm{CO}_{2}$ adsorption. This further supports the findings from the 306 kinetics studies and in-situ DRIFTS, which Ir sites impacted adsorption and activation 307 of $\mathrm{CO}_{2}$ and restricted carbon deposits during the DRM.

308

309

310 

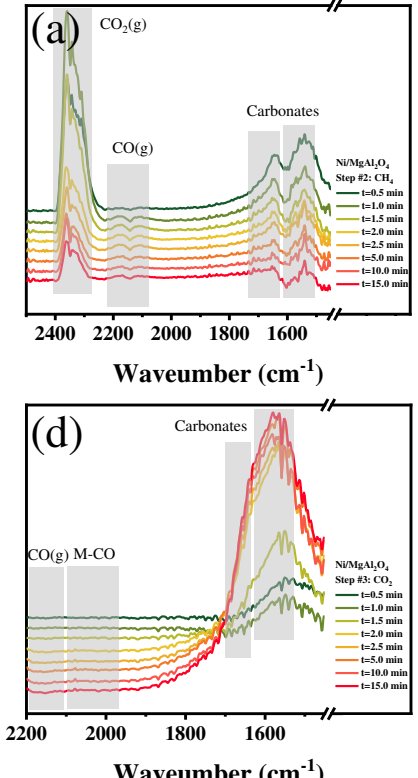

(g)

Step \#1: $\mathrm{CO}_{2}$

$\mathrm{CO}_{2}$

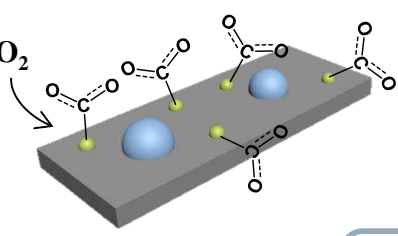

$$
\mathrm{CO}_{2}(\mathrm{~g}) \rightarrow \mathrm{CO}_{3}^{2-\text {,ads }}
$$

$\mathrm{CH}_{4} \rightarrow \mathrm{H}^{*}+\mathrm{CH}_{\mathrm{x}}{ }^{*} \quad \mathrm{CO}_{2}(\mathrm{~g}) \rightarrow \mathrm{CO}_{2} *$

$\mathrm{CO}_{3^{2} \text {,ads }} \rightarrow \mathrm{CO}_{2}(\mathrm{~g}) \quad \mathrm{CO}_{2}{ }^{*}+\mathrm{CH}{ }^{*} \rightarrow \mathrm{CO}(\mathrm{g})$

(h)

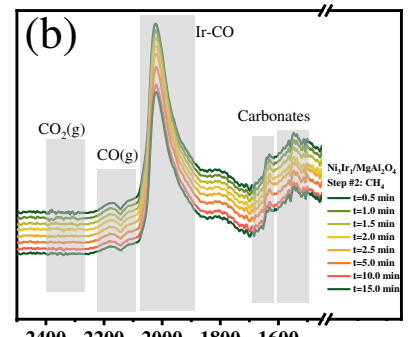

Waveumber $\left(\mathrm{cm}^{-1}\right)$
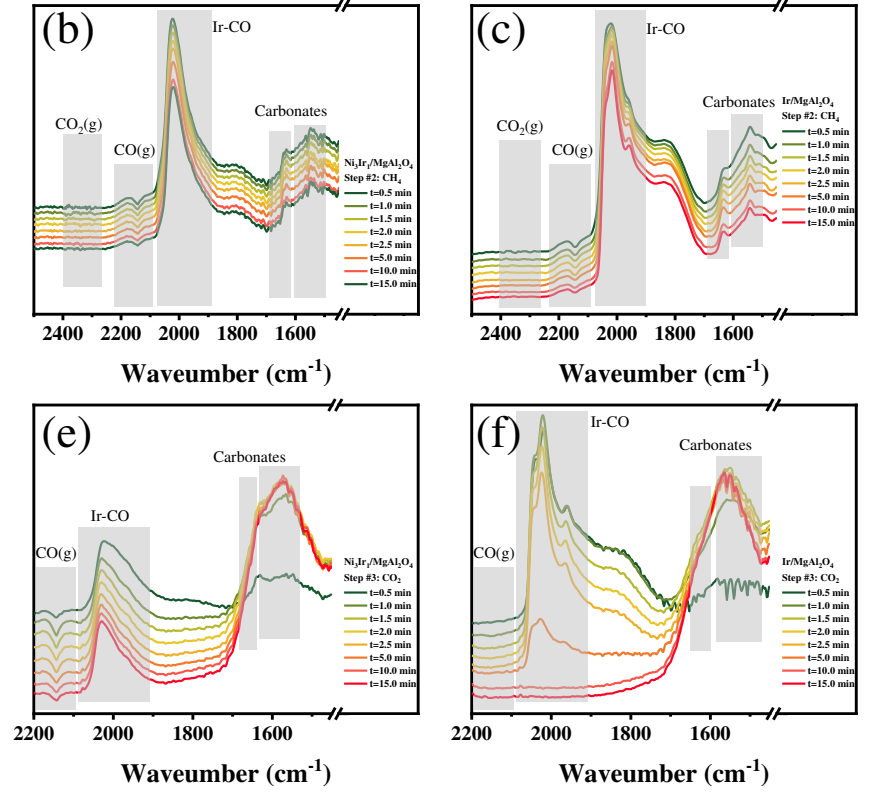

$\begin{array}{lllll}2400 & 2200 & 2000 & 1800 & 1600\end{array}$

Waveumber $\left(\mathrm{cm}^{-1}\right)$

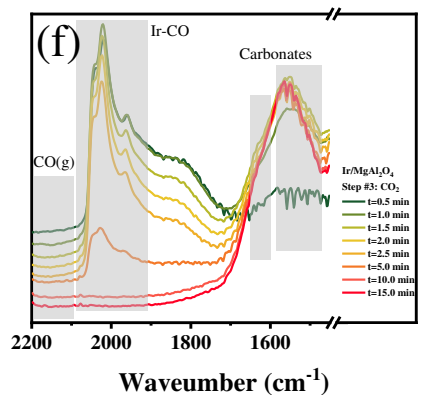

Waveumber $\left(\mathrm{cm}^{-1}\right)$

Step \#2: $\mathrm{CH}_{4} \mathrm{CO}_{2} \quad \mathrm{CH}_{4} \quad$ Step \#3: $\mathrm{CO}_{2}$ $\mathrm{CO}_{2}$
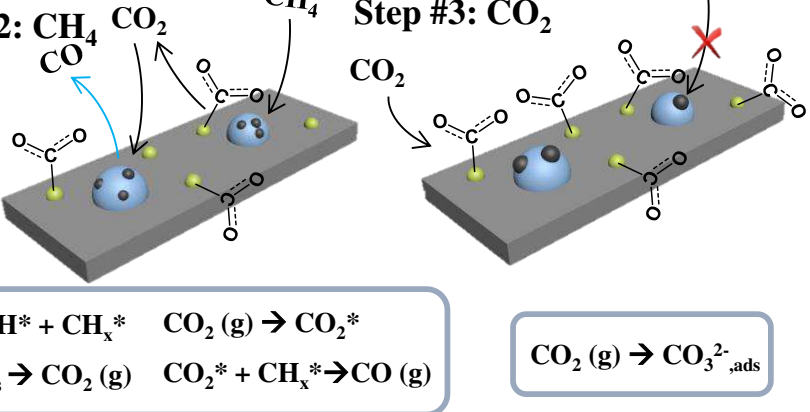

$\mathrm{CO}_{2}(\mathrm{~g}) \rightarrow \mathrm{CO}_{3}{ }^{2-}$,ads

$\mathrm{CO}_{2}$

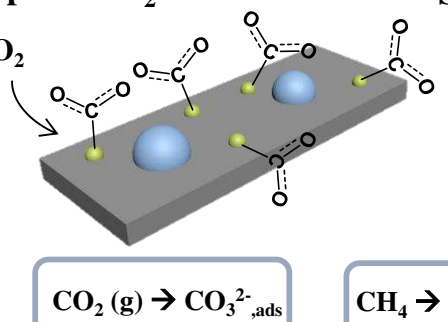

Step \#2: $\mathrm{CH}_{4} \mathrm{CO}^{\mathrm{CH}_{4}}$

co

\section{TPSR-MS analysis of the activation of methane and the elimination of carbon}

\section{deposits}

The activation and dissociation of $\mathrm{CH}_{4}$ is the main cause of carbon deposition 
during DRM. Temperature programmed surface reaction-mass (TPSR-MS) was used to explore the activation ability of $\mathrm{CH}_{4}$ during the DRM process. First, $\mathrm{CH}_{4}$ was introduced during the temperature-programming process (Figs. S14a and S15). The $\mathrm{Ni} / \mathrm{MgAl}_{2} \mathrm{O}_{4}, \mathrm{Ni}_{3} \mathrm{Ir}_{1} / \mathrm{MgAl}_{2} \mathrm{O}_{4}$, and $\mathrm{Ir} / \mathrm{MgAl}_{2} \mathrm{O}_{4}$ catalysts exhibited $\mathrm{CH}_{4}$ activation abilities at 289,328 , and $347^{\circ} \mathrm{C}$, respectively. The carbon species generated by the dissociation of $\mathrm{CH}_{4}$ blocked the active sites, restricting the activation of $\mathrm{CH}_{4}$. This caused the $\mathrm{CH}_{4}$ activation ability to decrease at 490,610 , and $590{ }^{\circ} \mathrm{C}$, respectively. This indicates that $\mathrm{Ni}$ was better than $\mathrm{Ir}$ for dissociation of $\mathrm{CH}_{4}$, and the dissociation rate increased with raising temperature.

Subsequently, TPSR-MS was performed on the catalysts after $\mathrm{CH}_{4}$ treatment to explore how the different catalytic systems eliminate carbon deposits in a $\mathrm{CO}_{2}$ atmosphere (Fig. S14b). Overall, the carbon removal temperature on $\mathrm{Ni} / \mathrm{MgAl}_{2} \mathrm{O}_{4}$ was higher than that on $\mathrm{Ni}_{3} \operatorname{Ir}_{1} / \mathrm{MgAl}_{2} \mathrm{O}_{4}$ and $\mathrm{Ir} / \mathrm{MgAl}_{2} \mathrm{O}_{4}$, which confirmed the $\mathrm{Ni}_{3} \mathrm{Ir}_{1} / \mathrm{MgAl}_{2} \mathrm{O}_{4}$ and $\mathrm{Ir} / \mathrm{MgAl}_{2} \mathrm{O}_{4}$ catalysts had stronger carbon removal abilities. The $\mathrm{Ni} / \mathrm{MgAl}_{2} \mathrm{O}_{4}$ catalyst had a relatively small amount of activated $\mathrm{CH}_{4}$ due to the blockage of active sites at lower temperatures, and the amount of carbon deposits and the resulting peak area were both relatively small. The above results show that $\mathrm{Ni}_{3} \mathrm{Ir}_{1} / \mathrm{MgAl}_{2} \mathrm{O}_{4}$ and $\mathrm{Ir} / \mathrm{MgAl}_{2} \mathrm{O}_{4}$ which followed path $\mathrm{B}$ had advantages in the process of activating $\mathrm{CO}_{2}$ and removing carbon species.

Raman spectra of the catalysts treated with $\mathrm{CH}_{4}$ showed that all of them had Dband and G-band carbon peaks (Fig. S16) and the carbon content followed Ni-Ir $>$ Ir $>$ $\mathrm{Ni}$, which was consistent with the TPSR-MS- $\mathrm{CO}_{2}$ results. In addition, the ratio of the D-band to the G-band indicated that the catalysts formed the same type of carbon species upon the dissociation of $\mathrm{CH}_{4}$. The different temperatures for $\mathrm{CO}_{2}$ removal reflect the difference in the activation mechanism of $\mathrm{CO}_{2}$ as described in the previous section.

\section{Theoretical assessment of $\mathrm{CO}_{2}$ activation on supported metal catalyst}

As shown above, the activation of $\mathrm{CO}_{2}$ over metal surface is critical for the efficient removal of carbon deposits during DRM. DFT calculations were further 
performed to understand the difference between $\mathrm{Ir}$ and $\mathrm{Ni}$ on $\mathrm{CO}_{2}$ activation at a molecular level. Herein, a Ni 8 cluster, a $\mathrm{Ir}_{8}$ cluster, and two $\mathrm{Ni}_{6} \mathrm{Ir}_{2}$ clusters with distinct configurations (denoted as $\mathrm{Ni}_{6} \mathrm{Ir}_{2} / \mathrm{MgAl}_{2} \mathrm{O}_{4}$-a and $\mathrm{Ni}_{6} \mathrm{Ir}_{2} / \mathrm{MgAl}_{2} \mathrm{O}_{4}-\mathrm{b}$ ) were constructed on a $\mathrm{MgAl}_{2} \mathrm{O}_{4}$ (100) surface for modeling the $\mathrm{Ir} / \mathrm{MgAl}_{2} \mathrm{O}_{4}, \mathrm{Ni} / \mathrm{MgAl}_{2} \mathrm{O}_{4}$ and $\mathrm{Ni}_{3} \mathrm{Ir} / \mathrm{MgAl}_{2} \mathrm{O}_{4}$ catalysts, respectively (Fig. 4a). Previous studies indicate that such $\mathrm{M}_{8}$ $(\mathrm{M}=$ metal) clusters were sufficient to reflect the characteristic of supported metal nanoparticles. ${ }^{[44-45]}$

Considering that the elimination of carbon deposits during DRM mainly depends on the active $\mathrm{O}^{*}$ species generated from $\mathrm{CO}_{2}$ dissociation ${ }^{[46-50]}$, we therefore focused on the adsorption and dissociation processes of $\mathrm{CO}_{2}$ at the metal-support interface. As shown in Fig. 4b, $\mathrm{CO}_{2}$ adsorption was much stronger on $\mathrm{Ir}_{8} / \mathrm{MgAl}_{2} \mathrm{O}_{4}$ than $\mathrm{Ni}_{8} / \mathrm{MgAl}_{2} \mathrm{O}_{4}(-2.14 \mathrm{eV}$ vs $-1.14 \mathrm{eV})$, consistent with the in-situ DRIFTS experiments. For $\mathrm{Ni}_{6} \mathrm{Ir}_{2} / \mathrm{MgAl}_{2} \mathrm{O}_{4}$, the adsorption energy of $\mathrm{CO}_{2}$ was between those for the $\mathrm{Ir}_{8}$ and $\mathrm{Ni}_{8}$ clusters, no matter the $\mathrm{C}$ atom of the adsorbed $\mathrm{CO}_{2}$ on the $\mathrm{Ni}_{6} \mathrm{Ir}_{2}$ clusters was bound to the $\mathrm{Ni}$ site (i.e., $\mathrm{Ni}_{6} \mathrm{Ir}_{2} / \mathrm{MgAl}_{2} \mathrm{O}_{4}-\mathrm{a} ;-1.33 \mathrm{eV}$ ) or the Ir site (i.e., $\mathrm{Ni}_{6} \mathrm{Ir}_{2} / \mathrm{MgAl}_{2} \mathrm{O}_{4}-\mathrm{b}$; $1.77 \mathrm{eV})$

DFT calculations showed that the $\mathrm{CO}_{2}$ dissociation $\left(\mathrm{CO}_{2} * \rightarrow \mathrm{CO}^{*}+\mathrm{O}^{*}\right.$, Fig. $\left.4 \mathrm{~b}\right)$ at the $\mathrm{Ir}_{8} / \mathrm{MgAl}_{2} \mathrm{O}_{4}$ interface was exothermic by $-0.41 \mathrm{eV}$ with an activation barrier of $1.48 \mathrm{eV}$, which was considerably lower than that on $\mathrm{Ni}_{8} / \mathrm{MgAl}_{2} \mathrm{O}_{4}$ interface $(2.18 \mathrm{eV})$. The difference of the activation barrier for $\mathrm{CO}_{2}$ dissociation indicates, compared with the $\mathrm{Ni}_{8}$ cluster, the generation of $\mathrm{O}^{*}$ species on the $\mathrm{Ir}_{8}$ cluster was much more efficient, rendering a fast elimination of carbon deposits and thus a high catalyst stability during DRM. For the two $\mathrm{Ni}_{6} \mathrm{Ir}_{2} / \mathrm{MgAl}_{2} \mathrm{O}_{4}$ models, $\mathrm{CO}_{2}$ was dissociated on $\mathrm{Ni}_{6} \mathrm{Ir}_{2} / \mathrm{MgAl}_{2} \mathrm{O}_{4}-\mathrm{a}$ with the formed $\mathrm{CO}^{*}$ species bound to a $\mathrm{Ni}$ site via a $\mathrm{C}-\mathrm{Ni}$ coronation and the formed $\mathrm{O}^{*}$ atom bound to a vicinal $\mathrm{Ir}$ site, while these two moieties formed on $\mathrm{Ni}_{6} \mathrm{Ir}_{2} / \mathrm{MgAl}_{2} \mathrm{O}_{4}-$ b were bound to the $\mathrm{Ni}$ and $\mathrm{Ir}$ sites inversely. $\mathrm{CO}_{2}$ dissociation on $\mathrm{Ni}_{6} \mathrm{Ir}_{2} / \mathrm{MgAl}_{2} \mathrm{O}_{4}-\mathrm{a}$ showed a much lower activation barrier than that for $\mathrm{Ni}_{6} \mathrm{Ir}_{2} / \mathrm{MgAl}_{2} \mathrm{O}_{4}-\mathrm{b}$ (1.69 vs. 2.21 eV, Fig. 4b), further reflecting different stabilities of the incipiently formed $\mathrm{CO}^{*}$ and $\mathrm{O}^{*}$ species at the transition state (TS) of $\mathrm{CO}_{2}$ dissociation on the $\mathrm{Ir}$ and Ni sites (TS structures shown in Fig. S17). 
In order to unveil the determining factors on the activity of $\mathrm{CO}_{2}$ dissociation, adsorption energies for $\mathrm{O}$ atom and $\mathrm{CO}$ on the supported $\mathrm{M}_{8}$ clusters were calculated 382 independently to compare the stabilities of these two species on different metal sites. As shown in Fig. 4c, the $\mathrm{CO}_{2}$ dissociation barrier presented a nearly linear correlation with the $\mathrm{O}$ adsorption energy, while no apparent correlation was observed between the $\mathrm{CO}_{2}$ dissociation barrier and the $\mathrm{CO}$ adsorption energy. These data clearly imply that the activity of $\mathrm{CO}_{2}$ dissociation is mainly determined by the stabilization of the $\mathrm{O}^{*}$ 387 species at the TS, which prefers the Ir site over the Ni site. The projected density of states (DOS) distributions of adsorbed $\mathrm{O}$ and $\mathrm{M}_{8}$ clusters were further analyzed (Fig. 4d) to obtain a deeper understanding of the higher oxygen affinity of Ir. It is found that the antibonding states of $\mathrm{O}_{2 p}$ became more populated in 391 the trend of $\mathrm{Ir}_{8} / \mathrm{MgAl}_{2} \mathrm{O}_{4}, \mathrm{Ni}_{6} \mathrm{Ir}_{2} / \mathrm{MgAl}_{2} \mathrm{O}_{4}-\mathrm{a}, \mathrm{Ni}_{8} / \mathrm{MgAl}_{2} \mathrm{O}_{4}$ and $\mathrm{Ni}_{6} \mathrm{Ir}_{2} / \mathrm{MgAl}_{2} \mathrm{O}_{4}-\mathrm{b}$, 392 accounting for the decrease of the stability of the $\mathrm{O}^{*}$ species and the increase of the $393 \mathrm{CO}_{2}$ dissociation barrier with this trend. Accordingly, the excellent stability of $\mathrm{Ir} / \mathrm{MgAl}_{2} \mathrm{O}_{4}$ and $\mathrm{Ni}_{3} \mathrm{Ir} / \mathrm{MgAl}_{2} \mathrm{O}_{4}$ catalysts during DRM is attributable to their stronger oxophilicity derived from metal Ir. 
(a)

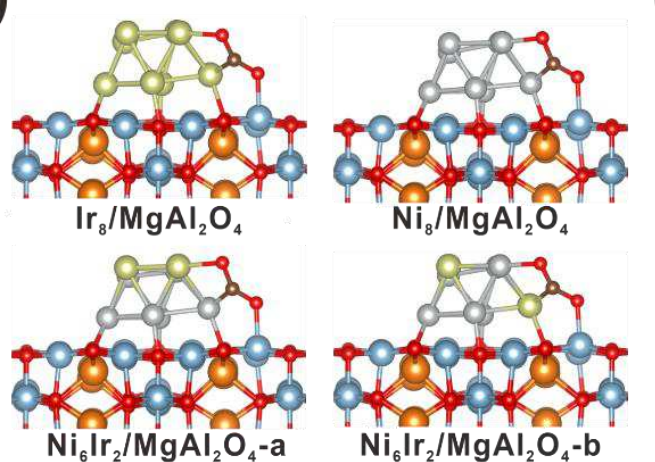

$\mathrm{Ni}_{6} \mathrm{Ir}_{2} / \mathrm{MgAI}_{2} \mathrm{O}_{4}-\mathrm{a}$ (b)

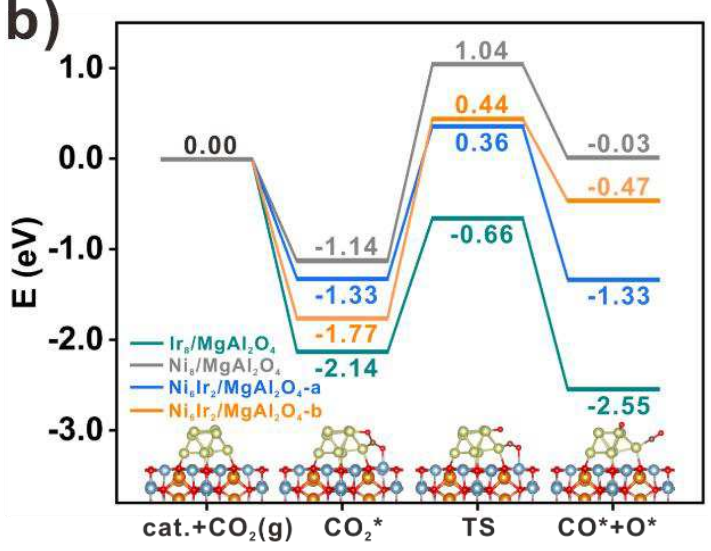

(c)
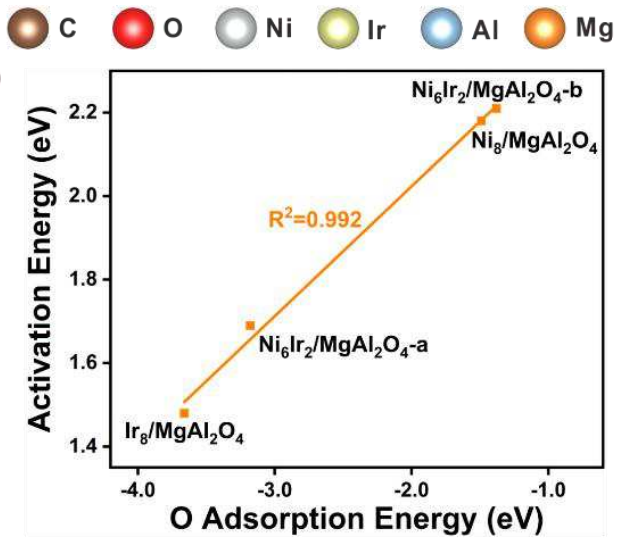

(d)
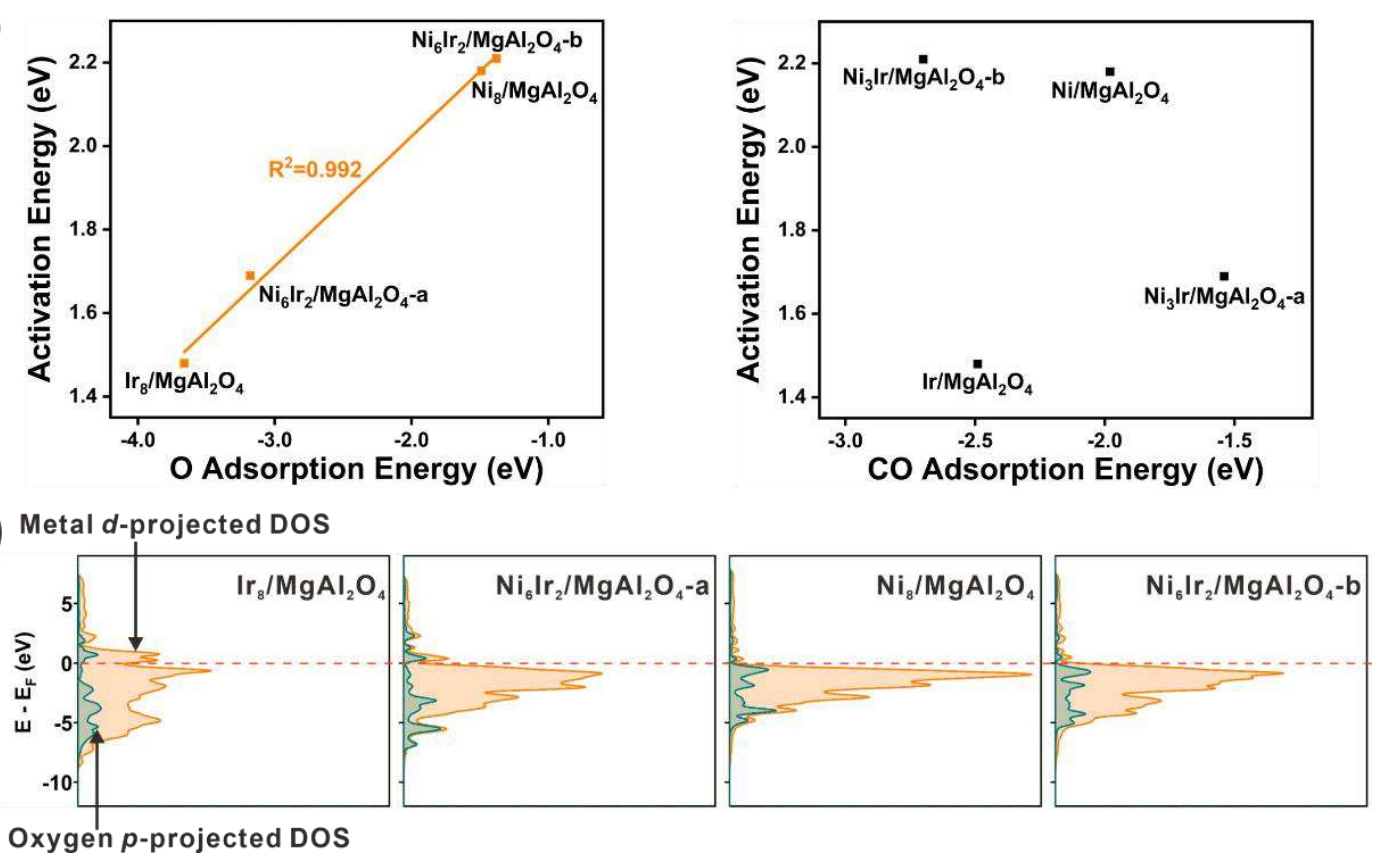

396

397

398

399

400

401

402

403

404

405

406

407

408

Fig. 4 (a) Four $\mathrm{M}_{8} / \mathrm{MgAl}_{2} \mathrm{O}_{4}$ catalyst models applied in the theoretical calculations of DRM (with $\mathrm{CO}_{2}$ adsorbed on the metal clusters). (b) DFT-derived energy changes of $\mathrm{CO}_{2}$ dissociative adsorption on $\mathrm{M}_{8} / \mathrm{MgAl}_{2} \mathrm{O}_{4}$. (c) Correlations of the $\mathrm{CO}_{2}$ activation barrier with the adsorption energies of O-atom and $\mathrm{CO}$ on $\mathrm{M}_{8} / \mathrm{MgAl}_{2} \mathrm{O}_{4}$. (d) Local density of states projected onto the adsorbed oxygen $2 \mathrm{p}$ state and $\mathrm{M}_{8}$ cluster $\mathrm{d}$ state for the oxygen chemisorption on $\mathrm{M}_{8} / \mathrm{MgAl}_{2} \mathrm{O}_{4}$.

\section{Mechanism of carbon deposits-elimination balance in DRM and its application}

With respect to the $\mathrm{Ni}_{3} \mathrm{Ir}_{1} / \mathrm{MgAl}_{2} \mathrm{O}_{4}$ catalyst, $\mathrm{Ni}$ mainly played the role of dissociating $\mathrm{CH}_{4}$, while $\mathrm{MgAl}_{2} \mathrm{O}_{4}$ not only acted as the support of the active metal sites, but also adsorbed $\mathrm{CO}_{2}$, forming carbonate species to enrich $\mathrm{CO}_{2}$. These carbonate species could be effectively activated by Ir to eliminate carbon species and inhibit 
carbon deposition. Since the main activation sites of $\mathrm{CH}_{4}$ and $\mathrm{CO}_{2}$ were different $(\mathrm{Ni}$ for $\mathrm{CH}_{4}$; $\mathrm{Ir}$ for $\mathrm{CO}_{2}$ ), the ratios of $\mathrm{Ni}$ and $\mathrm{Ir}$ atoms can greatly modulate the activation rates of $\mathrm{CH}_{4}$ and $\mathrm{CO}_{2}$.

During the DRM process, although the $\mathrm{Ni}-\mathrm{Ir} / \mathrm{MgAl}_{2} \mathrm{O}_{4}$ system had more carbon deposits, it maintained high stability. Interestingly, the formed carbon deposits seemed to have no effect on the catalytic activity. Therefore, carbon deposits formed on the catalysts along with the reaction were examined (Fig. 5a). We found that $\mathrm{Ni} / \mathrm{MgAl}_{2} \mathrm{O}_{4}$ had a faster rate of carbon deposition at the beginning and steadily increased. Further, as the carbon deposits increased, carbon chains blocked the contact between the active metal site and $\mathrm{CH}_{4}$. The reduction in the amount of active sites for $\mathrm{CH}_{4}$ dissociation led to a decrease in the rate of carbon deposition and DRM activity. In contrast, the $\mathrm{Ir} / \mathrm{MgAl}_{2} \mathrm{O}_{4}$ catalyst did not form carbon deposits during the 100 -hour test, while carbon deposits increased within the first 20 hours for $\mathrm{Ni}_{3} \operatorname{Ir}_{1} / \mathrm{MgAl}_{2} \mathrm{O}_{4}$, which was then stabilized with no significant additional increase until 100 hours.

Accordingly, we proposed a carbon deposits-elimination balance mechanism (Fig. $5 b$ ). With excessive $\mathrm{Ni}$, the activation rate of $\mathrm{CH}_{4}$ would be faster than that for $\mathrm{CO}_{2}$, and the dissociated carbon species would not be eliminated in time, leading to the generation of carbon deposits. This type of carbon deposition occurred on $\mathrm{Ni}$, the site activated by $\mathrm{CH}_{4}$, which would block some of the Ni active sites. With a decrease in the $\mathrm{Ni}$ active sites, the activation rate of $\mathrm{CH}_{4}$ decreased, resulting in a balance in the activation rate of $\mathrm{CH}_{4}$ and $\mathrm{CO}_{2}$. Similarly, excessive carbon deposits led to higher activation rates for $\mathrm{CO}_{2}$ than $\mathrm{CH}_{4}$, leading to the elimination of carbon deposits and exposing the $\mathrm{Ni}$ active sites previously covered. This caused the activation rate $\mathrm{of}_{4}$ to increase until it matched that for $\mathrm{CO}_{2}$ activation.

In the long-term test, this system gradually approached equilibrium until $v\left(\mathrm{CH}_{4}\right)$ $\approx v\left(\mathrm{CO}_{2}\right)\left(v\left(\mathrm{CH}_{4}\right)\right.$ : the activation rate of $\mathrm{CH}_{4} ; v\left(\mathrm{CO}_{2}\right)$ : the activation rate of $\left.\mathrm{CO}_{2}\right)$. This was also why numerous carbon deposits were observed in the $\mathrm{Ni}-\mathrm{Ir} / \mathrm{MgAl}_{2} \mathrm{O}_{4}$ catalytic system, but the effect on the catalytic activity was minimal. As $v\left(\mathrm{CH}_{4}\right)$ approached $v\left(\mathrm{CO}_{2}\right)$, the carbon deposits would no longer increase, but the existing carbon deposits would not be eliminated. In other words, the system achieved a balance between carbon 
deposition and elimination, and the overall reactivity was determined by the activation of $\mathrm{CO}_{2}$. Over the $\mathrm{Ni} / \mathrm{MgAl}_{2} \mathrm{O}_{4}$ catalyst, the dissociation of $\mathrm{CH}_{4}$ and the activation of $\mathrm{CO}_{2}$ occurred at the same active site, which did not follow this mechanism; thus, carbon deposits increased throughout the test. For the $\mathrm{Ni}_{3} \mathrm{Ir}_{1} / \mathrm{MgAl}_{2} \mathrm{O}_{4}$ catalyst, the Ni sites were reduced sufficiently such that the reaction system reached $v\left(\mathrm{CH}_{4}\right) \approx v\left(\mathrm{CO}_{2}\right)$ equilibrium after 20 hours.

Based on these results, $\mathrm{Ni}-\mathrm{Ir} / \mathrm{MgAl}_{2} \mathrm{O}_{4}$ catalysts were prepared with different $\mathrm{Ni} / \mathrm{Ir}$ ratios for a 100-hour test to assess carbon deposition (Figs. 5c-d, S18-S19). With an increase in the $\mathrm{Ir}$ content from $\mathrm{Ni} / \mathrm{Ir}=12 / 1$ to $1 / 3$, the initial $\mathrm{CH}_{4}$ conversion of the catalyst increased from $60.7 \%$ to $62.5 \%$, and the average conversion of $\mathrm{CH}_{4}$ increased from $59.1 \%$ to $62.4 \%$. With increasing the Ir content, the activity and stability both increased. When the Ir/Ni ratio was 2, both of the initial and average conversions reached the highest level, and there was no further impact with an additional increase of the Ir content. In addition, the carbon deposits decreased from $14.2 \mathrm{wt} \%(\mathrm{Ni} / \mathrm{Ir}=$ $12 / 1)$ to $0 \mathrm{wt} \%(\mathrm{Ir} / \mathrm{Ni}=2)$, and no carbon deposition occurred with further increasing the Ir content. This was because the increased Ir content brought more catalytic sites for $\mathrm{CO}_{2}$ activation, allowing the system to reach the equilibrium between carbon deposition and elimination faster. Therefore, while maintaining high activity, the amount of carbon deposits was regularly reduced during the test. As the number of $\mathrm{CO}_{2}$ activation sites increased, the activity of the rate-determining step in the reaction increased, and the system exhibited higher activity. This result was consistent with the balance theory, as when $\mathrm{Ir} / \mathrm{Ni}=2, v\left(\mathrm{CO}_{2}\right)$ matched $v\left(\mathrm{CH}_{4}\right)$ during the initial stage of the test. Therefore, the carbon deposition was almost negligible, with almost no differences between the initial activity and the average activity of the reaction, indicating an extremely high stability of the catalytic system.

We anticipated that a match between $v\left(\mathrm{CO}_{2}\right)$ and $v\left(\mathrm{CH}_{4}\right)$ in the initial state of the reaction by tuning the Ni-Ir relative contents would achieve a balance between the generation and elimination of carbon deposits, leading to a DRM catalytic system with zero carbon deposits. Because Ir is a precious metal, it was necessary to reduce the Ir content as much as possible. As shown in Figs. $5 \mathrm{c}-\mathrm{d}$, the $\mathrm{Ir} / \mathrm{Ni}$ ratio of 2 was found as 
the best catalyst ratio. We then conducted a 600 hours long-time test under the conditions of $650{ }^{\circ} \mathrm{C}$, GHSV $=40,000 \mathrm{~mL} \cdot \mathrm{g}^{-1} \cdot \mathrm{h}^{-1}$, and 1 bar (Fig. 5e). The initial conversion rates of $\mathrm{CH}_{4}$ and $\mathrm{CO}_{2}$ were $62.67 \%$ and $72.94 \%$, respectively, with no significant change in activity after 600 hours. Raman spectra of the spent catalyst showed no obvious signal peaks for amorphous carbon at $1334 \mathrm{~cm}^{-1}$ or $1598 \mathrm{~cm}^{-1}$ (Fig. 5f). In addition, no significant weight loss was observed from TGA (Fig. 5g). These results confirmed that no obvious carbon deposition occurred on the catalyst, consistent with the results of the catalytic system optimized based on our proposed theory.

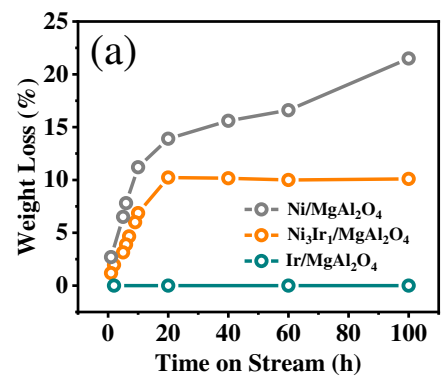

(b)
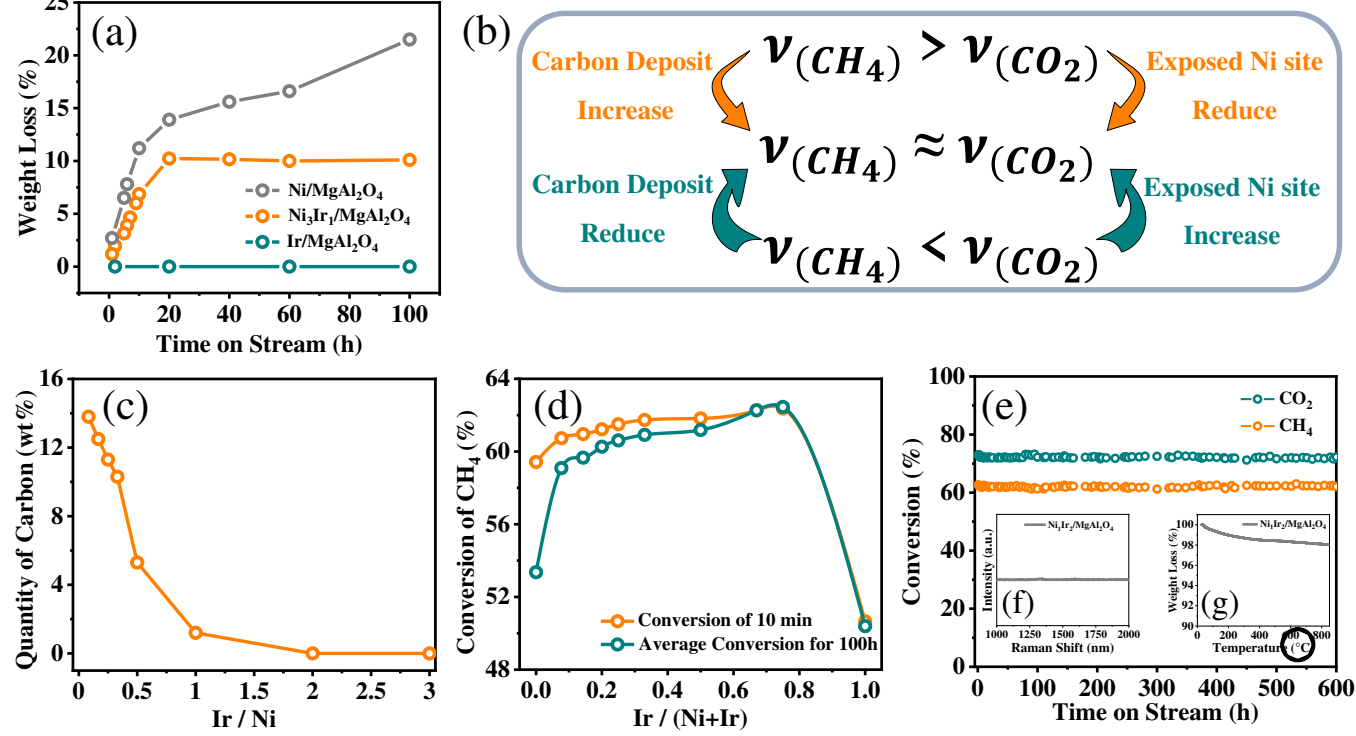

Fig. 5 (a) Relationship between carbon deposits and time on stream for $\mathrm{Ni} / \mathrm{MgAl}_{2} \mathrm{O}_{4}$, $\mathrm{Ni}_{3} \mathrm{Ir}_{1} / \mathrm{MgAl}_{2} \mathrm{O}_{4}$, and $\mathrm{Ir} / \mathrm{MgAl}_{2} \mathrm{O}_{4}$, (b) schematic diagram of the balance theory in DRM, (c) weight percent of carbon deposits from spent catalysts with varying Ir/Ni ratios, (d) relationship between the Ir content and catalytic activity, (e) catalytic performance during a long-term test of $\mathrm{Ni}_{1} \mathrm{Ir}_{2} / \mathrm{MgAl}_{2} \mathrm{O}_{4}$ for DRM, (f) Raman spectra, and (g) TGA of the spent catalysts after the long-term test of DRM.

\section{Conclusions}

Dry reforming of methane (DRM) to generate syngas can serve as a bridge for the high-volume utilization of greenhouse gases and synthesis of industrial platform molecules. The core of the stable DRM reaction is the equilibrium between efficient $\mathrm{CH}_{4}$ dissociation and $\mathrm{CO}_{2}$ activation. We designed and constructed an ultra-stable $\mathrm{Ni}$ - 
$\mathrm{Ir} / \mathrm{MgAl}_{2} \mathrm{O}_{4}$ alloy system for DRM showing high activity, where Ni played the role of 491 activating $\mathrm{CH}_{4}$ and $\mathrm{MgAl}_{2} \mathrm{O}_{4}$ adsorbed $\mathrm{CO}_{2}$ to form carbonate species that can be 492 effectively utilized by Ir to eliminate carbon species generated from $\mathrm{CH}_{4}$ activation on $493 \mathrm{Ni}$. Based on the feature of $\mathrm{Ni}$, Ir and $\mathrm{MgAl}_{2} \mathrm{O}_{4}$, we proposed a balance mechanism 494 between the active sites and the carbon deposits-eliminations over $\mathrm{Ni}_{1} \mathrm{Ir}_{2} / \mathrm{MgAl}_{2} \mathrm{O}_{4}$ 495 catalytic system, which achieved equilibrium of $v\left(\mathrm{CH}_{4}\right) \approx v\left(\mathrm{CO}_{2}\right)$ at the beginning of 496 the reaction, and effectively inhibited the generation of carbon deposits while 497 maintaining high activity and stability. This deeper understanding of the relationship 498 among the activity of $\mathrm{CH}_{4}$ dissociation, $\mathrm{CO}_{2}$ activation, and carbon deposition499 elimination would inspire new ideas on the rational design and development of novel 500 catalysts for activation of inert $\mathrm{C}_{1}$ molecules.

501 


\section{References}

5031 Emiel de Smit, E. \& Weckhuysen, B. M. The renaissance of iron-based Fischer-Tropsch 504 synthesis: on the multifaceted catalyst deactivation behaviour. Chem. Soc. Rev. 37, 2758-2781, 505 doi:10.1039/b805427d (2008).

5062 Xiong, H., Jewell, L. L. \& Coville, N. J. Shaped Carbons As Supports for the Catalytic 507 Conversion of Syngas to Clean Fuels. ACS Catal. 5, 2640-2658, doi:10.1021/acscatal.5b00090 $508 \quad$ (2015).

5093 Chen, Y. et al. Sintered precipitated iron catalysts with enhanced fragmentation-resistance 510 ability for Fischer-Tropsch synthesis to lower olefins. Catal. Sci. Technol. 8, 5943-5954, 511 doi:10.1039/c8cy01392f(2018).

5124 Chen, Y. et al. Ruthenium silica nanoreactors with varied metal-wall distance for efficient 513 control of hydrocarbon distribution in Fischer-Tropsch synthesis. J. Catal. 365, 429-439, doi:10.1016/j.jcat.2018.06.023 (2018).

Andrei Y. K., Wei C. \& Pascal F. Advances in the Development of Novel Cobalt Fischer-Tropsch Catalysts for Synthesis of Long-Chain Hydrocarbons and Clean Fuels. Chem. Rev. 107, 5, 1692-1744, doi:org/10.1021/cr050972v (2017).

Yentekakis, I. V. et al. Effect of support oxygen storage capacity on the catalytic performance of Rh nanoparticles for $\mathrm{CO}_{2}$ reforming of methane. Appl. Catal. B-Environ. 243, 490-501, doi:10.1016/j.apcatb.2018.10.048 (2019).

Zhang, Y. et al. $\mathrm{Ru} / \mathrm{TiO}_{2}$ Catalysts with Size-Dependent Metal/Support Interaction for Tunable Reactivity in Fischer-Tropsch Synthesis. ACS Catal. 10, 12967-12975, doi:10.1021/acscatal.0c02780 (2020).

Zhang, J.-C. et al. Robust Ruthenium-Saving Catalyst for High-Temperature Carbon Dioxide Reforming of Methane. ACS Catal. 10, 783-791, doi:10.1021/acscatal.9b03709 (2019).

Singha, R. K., Shukla, A., Sandupatla, A., Deo, G. \& Bal, R. Synthesis and catalytic activity of a Pd doped $\mathrm{Ni}-\mathrm{MgO}$ catalyst for dry reforming of methane. J. Mater. Chem. A 5, 15688-15699, doi:10.1039/c7ta04452f (2017).

Kobayashi, T., Furuya, T., Fujitsuka, H. \& Tago, T. Synthesis of Birdcage-type zeolite encapsulating ultrafine Pt nanoparticles and its application in dry reforming of methane. Chem. Eng. J. 377, doi:10.1016/j.cej.2018.10.140 (2019).

Rodriguez, J. A., Grinter, D. C., Liu, Z., Palomino, R. M. \& Senanayake, S. D. Ceria-based model catalysts: fundamental studies on the importance of the metal-ceria interface in $\mathrm{CO}$ oxidation, the water-gas shift, $\mathrm{CO}_{2}$ hydrogenation, and methane and alcohol reforming. Chem. Soc. Rev. 46, 1824-1841, doi:10.1039/c6cs00863a (2017).

Muraleedharan Nair, M. \& Kaliaguine, S. Structured catalysts for dry reforming of methane. New J. Chem. 40, 4049-4060, doi:10.1039/c5nj03268g (2016).

Li, S. \& Gong, J. Strategies for improving the performance and stability of Ni-based catalysts for reforming reactions. Chem. Soc. Rev. 43, 7245-7256, doi:10.1039/c4cs00223g (2014).

Tian, J., Ma, B., Bu, S., Yuan, Q. \& Zhao, C. One-pot synthesis of highly sintering- and cokingresistant Ni nanoparticles encapsulated in dendritic mesoporous $\mathrm{SiO}_{2}$ for methane dry reforming. Chem. Commun. (Camb) 54, 13993-13996, doi:10.1039/c8cc08284g (2018).

Tian, J. et al. Facile immobilization of Ni nanoparticles into mesoporous MCM-41 channels for efficient methane dry reforming. Chinese J. Catal. 40, 1395-1404, doi:10.1016/s1872- 
2067(19)63403-0 (2019).

Pakhare, D. \& Spivey, J. A review of dry $\left(\mathrm{CO}_{2}\right)$ reforming of methane over noble metal catalysts. Chem. Soc. Rev. 43, 7813-7837, doi:10.1039/c3cs60395d (2014).

Ochoa, A. et al. Deactivation dynamics of a Ni supported catalyst during the steam reforming of volatiles from waste polyethylene pyrolysis. Appl. Catal. B-Environ. 209, 554-565, doi:10.1016/j.apcatb.2017.02.015 (2017).

Lisiane V. M., Gary J., Burtron H. D. \& Fábio B. N. Production of Hydrogen from Ethanol: Review of Reaction Mechanism and Catalyst Deactivation. Chem. Rev. 112, 7, 4096-4123, doi: org/10.1021/cr2000114 (2012).

Saib, A. M. et al. Fundamental understanding of deactivation and regeneration of cobalt Fischer-Tropsch synthesis catalysts. Catal. Today 154, 271-282, doi:10.1016/j.cattod.2010.02.008 (2010).

Tsakoumis, N. E., Rønning, M., Borg, Ø., Rytter, E. \& Holmen, A. Deactivation of cobalt based Fischer-Tropsch catalysts: A review. Catal. Today 154, 162-182, doi:10.1016/j.cattod.2010.02.077 (2010).

Wang, C. et al. Coking and deactivation of a mesoporous $\mathrm{Ni}-\mathrm{CaO}-\mathrm{ZrO}_{2}$ catalyst in dry reforming of methane: A study under different feeding compositions. Fuel 143, 527-535, doi:10.1016/j.fuel.2014.11.097 (2015).

Wang, F. et al. Enhanced catalytic performance of Ir catalysts supported on ceria-based solid solutions for methane dry reforming reaction. Catal. Today 281, 295-303, doi:10.1016/j.cattod.2016.03.055 (2017).

Mortola VB, Damyanova S, Zanchet D, Bueno JMC. Surface and structural features of Pt/CeO $2^{-}$ $\mathrm{La}_{2} \mathrm{O}_{3}-\mathrm{Al}_{2} \mathrm{O}_{3}$ catalysts for partial oxidation and steam reforming of methane. Appl. Catal. BEnviron. 107, 221-236, doi: 10.1016/j.apcatb.2011.07.012 (2011).

4 Jeong D-W, Potdar HS, Shim J-O, Jang W-J, Roh H-S. $\mathrm{H}_{2}$ production from a single stage watergas shift reaction over $\mathrm{Pt} / \mathrm{CeO}_{2}, \mathrm{Pt} / \mathrm{ZrO}_{2}$, and $\mathrm{Pt} / \mathrm{Ce}_{(1-\mathrm{x})} \mathrm{Zr}_{(\mathrm{x})} \mathrm{O}_{2}$ catalysts. Int. J. Hydrog. Energy 38, 4502-4507, doi: 10.1016/j.ijhydene.2013.01.200 (2013)

Alipour, Z., Rezaei, M. \& Meshkani, F. Effect of Ni loadings on the activity and coke formation of $\mathrm{MgO}$-modified $\mathrm{Ni} / \mathrm{Al}_{2} \mathrm{O}_{3}$ nanocatalyst in dry reforming of methane. J. Energy Chem. 23, 633638, doi:10.1016/s2095-4956(14)60194-7 (2014).

Jabbour, K., Massiani, P., Davidson, A., Casale, S. \& El Hassan, N. Ordered mesoporous “onepot" synthesized $\mathrm{Ni}-\mathrm{Mg}(\mathrm{Ca})-\mathrm{Al}_{2} \mathrm{O}_{3}$ as effective and remarkably stable catalysts for combined steam and dry reforming of methane (CSDRM). Appl. Catal. B-Environ. 201, 527-542, doi:10.1016/j.apcatb.2016.08.009 (2017).

Ay, H. \& Üner, D. Dry reforming of methane over $\mathrm{CeO}_{2}$ supported Ni, Co and Ni-Co catalysts. Appl. Catal. B-Environ. 179, 128-138, doi:10.1016/j.apcatb.2015.05.013 (2015).

Faria, E. C., Neto, R. C. R., Colman, R. C. \& Noronha, F. B. Hydrogen production through $\mathrm{CO}_{2}$ reforming of methane over $\mathrm{Ni} / \mathrm{CeZrO}_{2} / \mathrm{Al}_{2} \mathrm{O}_{3}$ catalysts. Catal. Today 228, 138-144, doi:10.1016/j.cattod.2013.10.058 (2014).

Jin-Hong Kim, Dong Jin Suh, Tae-Jin Park, Kyung-Lim Kim. Effect of metal particle size on coking during $\mathrm{CO}_{2}$ reforming of $\mathrm{CH}_{4}$ over Ni-alumina aerogel catalysts. Appl. Catal. A-Gen. 197, 191-200, doi: 10.1016/S0926-860X(99)00487-1 (2000).

Kunitski, M. et al. Double-slit photoelectron interference in strong-field ionization of the neon dimer. Nat. Commun. 10, 1, doi:10.1038/s41467-018-07882-8 (2019). 
Cao, K. et al. Nickel catalyst with atomically-thin meshed cobalt coating for improved durability in dry reforming of methane. J. Catal. 373, 351-360, doi:10.1016/j.jcat.2019.04.017 (2019).

32 Theofanidis, S. A., Galvita, V. V., Poelman, H. \& Marin, G. B. Enhanced Carbon-Resistant Dry Reforming Fe-Ni Catalyst: Role of Fe. ACS Catal. 5, 3028-3039, doi:10.1021/acscatal.5b00357 (2015).

33 Song Y. et al. Dry reforming of methane by stable Ni-Mo nanocatalysts on single-crystalline MgO. Science 367, 777-781, doi: 10.1126/science.aav2412 (2020).

34 Pan, C., Guo, Z., Dai, H., Ren, R. \& Chu, W. Anti-sintering mesoporous Ni-Pd bimetallic catalysts for hydrogen production via dry reforming of methane. Int. J. Hydrog. Energy 45, 16133-16143, doi:10.1016/j.ijhydene.2020.04.066 (2020).

35 Garc í a-Di é guez, M., Pieta, I. S., Herrera, M. C., Larrubia, M. A. \& Alemany, L. J. Nanostructured Pt- and Ni-based catalysts for $\mathrm{CO}_{2}$-reforming of methane. J. Catal. 270, 136145, doi:10.1016/j.jcat.2009.12.010 (2010).

36 de Miguel, S. R. et al. Influence of Pt addition to Ni catalysts on the catalytic performance for long term dry reforming of methane. Appl. Catal. A-Gen. 435-436, 10-18, doi:10.1016/j.apcata.2012.05.030 (2012).

37 Al-Fatesh, A. et al. $\mathrm{Rh}$ promoted and $\mathrm{ZrO}_{2} / \mathrm{Al}_{2} \mathrm{O}_{3}$ supported $\mathrm{Ni} / \mathrm{Co}$ based catalysts: High activity for $\mathrm{CO}_{2}$ reforming, steam- $\mathrm{CO}_{2}$ reforming and oxy- $\mathrm{CO}_{2}$ reforming of $\mathrm{CH}_{4}$. Int. J. Hydrog. Energy 43, 12069-12080, doi:10.1016/j.ijhydene.2018.04.152 (2018).

38 Turap, Y. et al. $\mathrm{Co}-\mathrm{Ni}$ alloy supported on $\mathrm{CeO}_{2}$ as a bimetallic catalyst for dry reforming of methane. Int. J. Hydrog. Energy 45, 6538-6548, doi:10.1016/j.ijhydene.2019.12.223 (2020).

39 Siang, T. J. et al. Hydrogen production from $\mathrm{CH}_{4}$ dry reforming over bimetallic Ni-Co/ $\mathrm{Al}_{2} \mathrm{O}_{3}$ catalyst. J. Energy Inst. 91, 683-694, doi:10.1016/j.joei.2017.06.001 (2018).

40 Song, K. et al. Effect of alloy composition on catalytic performance and coke-resistance property of $\mathrm{Ni}-\mathrm{Cu} / \mathrm{Mg}(\mathrm{Al}) \mathrm{O}$ catalysts for dry reforming of methane. Appl. Catal. B-Environ. 239, 324-333, doi:10.1016/j.apcatb.2018.08.023 (2018).

41 Al-Fatesh, A. S. Promotional effect of $\mathrm{Gd}$ over Ni/ $\mathrm{Y}_{2} \mathrm{O}_{3}$ catalyst used in dry reforming of $\mathrm{CH}_{4}$ for $\mathrm{H}_{2}$ production. Int. J. Hydrog. Energy 42, 18805-18816, doi:10.1016/j.ijhydene.2017.06.165 (2017).

42 Das $\mathrm{S}$, et al. Effect of Partial Fe Substitution in $\mathrm{La}_{0.9} \mathrm{Sr}_{0.1} \mathrm{NiO}_{3}$ Perovskite-Derived Catalysts on the Reaction Mechanism of Methane Dry Reforming. ACS Catal. 10, 12466-12486 (2020).

43 Azancot L, Bobadilla LF, Centeno MA, Odriozola JA. IR spectroscopic insights into the cokingresistance effect of potassium on nickel-based catalyst during dry reforming of methane. App. Catal. B-Environ. 285, (2021).

44 Cheng, F., Duan, X. \& Xie, K. Dry reforming of methane by stable Ni nanocrystals on porous single-crystalline $\mathrm{MgO}$ monoliths at reduced temperature. Angew. Chem. Int. Ed. 60, 1879218799, doi:10.1002/anie.202106243 (2021).

45 Guo, Y.-P., Li, W.-Y. \& Feng, J. Reaction pathway of $\mathrm{CH}_{4} / \mathrm{CO}_{2}$ reforming over $\mathrm{Ni8} / \mathrm{MgO}(100)$. Surf. Sci. 660, 22-30, doi:10.1016/j.susc.2017.02.010 (2017).

46 Akri, M. et al. Atomically dispersed nickel as coke-resistant active sites for methane dry reforming. Nat. Commun. 10, 5181, doi:10.1038/s41467-019-12843-w (2019).

$4 \mathrm{Wu}$, P. et al. Cooperation of $\mathrm{Ni}$ and $\mathrm{CaO}$ at interface for $\mathrm{CO}_{2}$ reforming of $\mathrm{CH}_{4}$ : A combined theoretical and experimental study. ACS Catal. 9, 10060-10069, doi:10.1021/acscatal.9b02286 
633

634

635

636

637

638

639

640

641

(2019).

48 Tang, Y. et al. Synergy of single-atom $\mathrm{Ni}_{1}$ and $\mathrm{Ru}_{1}$ sites on $\mathrm{CeO}_{2}$ for dry reforming of $\mathrm{CH}_{4} . J$. Am. Chem. Soc. 141, 7283-7293, doi: 10.1021/jacs.8b10910 (2019).

49 Joo, S. et al. Enhancing thermocatalytic activities by upshifting the d-band center of exsolved Co-Ni-Fe ternary alloy nanoparticles for the dry reforming of methane. Angew. Chem. Int. Ed. 60, 15912-15919, doi:10.1002/anie.202101335 (2021).

50 Foppa, L. et al. Contrasting the role of Ni/A12O3 interfaces in water-gas shift and dry reforming of methane. J. Am. Chem. Soc. 139, 17128-17139, doi: 10.1021/jacs.7b08984 (2017). 


\section{Supplementary Files}

This is a list of supplementary files associated with this preprint. Click to download.

- NilrSlfinal.pdf 